\title{
Zeolite Application in Wastewater Treatment
}

\author{
Luciano Fernandes de Magalhães $\mathbb{D}^{1},{ }^{1}$ Gilberto Rodrigues da Silva $\mathbb{D}$, ${ }^{1}$ \\ and Antônio Eduardo Clark Peres $\mathbb{( D}^{2}$ \\ ${ }^{1}$ Department of Mining Engineering, Federal University of Minas Gerais, MG, Brazil \\ ${ }^{2}$ Department of Metallurgical and Materials Engineering, Federal University of Minas Gerais, MG, Brazil
}

Correspondence should be addressed to Luciano Fernandes de Magalhães; lucianofmag@demin.ufmg.br

Received 17 December 2021; Revised 25 January 2022; Accepted 27 January 2022; Published 9 February 2022

Academic Editor: Muhammad Raziq Rahimi Kooh

Copyright $\odot 2022$ Luciano Fernandes de Magalhães et al. This is an open access article distributed under the Creative Commons Attribution License, which permits unrestricted use, distribution, and reproduction in any medium, provided the original work is properly cited.

\begin{abstract}
As a scarce natural resource, the preservation of water quality is of fundamental importance to guarantee its availability for future generations. Due to the increasing industrial activity, effluents are generated with a series of chemical compounds, such as nitrogenous, phosphoric, and organic compounds, heavy metals, and dyes which, if improperly disposed of, contribute to contamination, followed by significant environmental impacts, in addition to the damage to human health. The adsorption technique is an effective approach for removing contaminants from effluents, showing high versatility, due to the use of various materials as adsorbents. Belonging to a wide variety of materials, zeolites reveal to be a promising adsorbent. Zeolites are minerals found in nature or which can be synthesized from industrial residues, standing out in the treatment of contaminated effluents. Zeolite removal efficiency depends on the contaminant to be removed and can reach up to $96 \%$ for heavy metals, $90 \%$ for phosphoric compounds, $96 \%$ for dyes, $80 \%$ for nitrogen compounds, and $89 \%$ for organics. Aiming at the identification of the more relevant findings and research gaps to advance the use of zeolites in the large-scale treatment of industrial effluents, a review on the recent application of zeolites is needed. This paper presents a global view of zeolites, and a review is conducted on several recent studies using zeolites as adsorbents for the contaminants considered, indicating the main characteristics of the various adsorption systems, demonstrating the particularities of each process, and aiming to reveal useful information to provide future research, in addition to identifying points that need further investigation.
\end{abstract}

\section{Introduction}

Water is an essential element for life on Earth. Although about $70 \%$ of the planet's surface is covered with water, only a small portion of this volume can be consumed as freshwater. Still, much of the freshwater is in the form of glaciers, and therefore, it is not available for consumption [1]. In addition, freshwater is not evenly distributed across continents, with some parts of the world having large reserves, while others suffer from lack. Allied to the problem of the relative scarcity of this limited resource and its irregular distribution, the growing industrial activity has contributed significantly to the contamination of the waters through the disposal, often inadequate, of effluents generated [2].

As society's demand for consumption increases, the food, cosmetics, mining and metallurgy, chemical and phar- maceutical industries, among others, intensified their production, and consequently, greater attention has been paid to the effluents generated. The presence of several contaminating elements present in wastewater is common, such as heavy metals (e.g., lead, arsenic, chromium, and mercury) [3], compounds based on nitrogen [4] and phosphorus [5], dyes [6], and various organic compounds [7]. All these elements, if disposed of untreated, contaminate water, soil, plants, and animals and can eventually reach humans. For the organism, these compounds have high toxicity, and depending on the dosage and time of exposure, a series of disorders can occur. Studies indicate the appearance of several types of cancer, genetic abnormalities, damage to organs and systems, and psychological disorders due to exposure to heavy metals and organic compounds $[8,9]$. In addition, the environment can also suffer significant damage when 
exposed to the inadequate disposal of effluents, especially those rich in dyes, nitrogen, and phosphorus. In the presence of abundance, these elements can cause eutrophication of water bodies, eliminating all aquatic life [10].

Several forms of wastewater treatment have been developed over the decades, to remove contaminating elements from wastewater, before their disposal. Techniques such as chemical precipitation [11], ionic flotation [12], electrodialysis [13], and biological treatment [14] are efficient in the treatment of effluents, but they have some disadvantages such as the generation of toxic waste that requires adequate storage, high demand for chemical reagents, high energy cost, and limited efficiency to remove contaminants with low concentration [15-18]. In contrast, the adsorption technique is promising and possesses several advantages over other techniques, which justifies its application in the treatment of effluents. One of the great advantages of the technique is its versatility, as it allows the use of various materials as adsorbents, from activated carbon to industrial wastes [19].

Several materials have been used as adsorbents to remove contaminants from water. Activated carbon, biochar, clay minerals, and advanced materials are among the most studied materials for wastewater decontamination. These materials possess the necessary features to be used for this purpose, e.g., high surface area, negative electric charge (clay minerals), and micro-/mesoporous (carbonbased) materials [20, 21]. However, some disadvantages limit their use on a large scale. Activated carbon and biochar are products of the calcination of organic matter, e.g., bamboo, corn straw, and rice husk, in an anaerobic atmosphere. The properties of the final product can vary in a wide range since it is a function of the precursor used. Another disadvantage is the high cost of production, whereas the calcination temperature can be as high as $900^{\circ} \mathrm{C}$ [20].

Clays are composed of phyllosilicate minerals. These minerals possess sheet-like structures, exhibiting a high specific area. Furthermore, their atomic structure provides a natural negative charge that is neutralized by a variety of cations. These properties make clays a material with the potential to be used as adsorbents. However, they are composed of a wide range of minerals, and their removal potential may be reduced or present great variation [22]. Their modification can be enhanced by a series of treatments, e.g., thermal, acidic, and surfactant modification, but these treatments increase the process costs [23].

A relatively new class of materials to be used in water treatment are the advanced materials and the nanomaterials, e.g., alumina, silica, titanium oxide, and zirconia. These materials possess small size, high specific energy, and high reactivity [24]. Among them, zeolite is a class of material that has attracted the attention of the scientific community and has the potential to be used as an adsorbent in the elimination of contaminating elements in effluents. These minerals, found in nature or synthesized, have a microporous crystalline structure (with pores opening smaller than $20 \AA$ ) [25], which guarantees their application for several purposes, such as gas separation [26], water softeners [27], catalyst [28], addition for Portland cement [29], and applica- tions in health and animal food [30]. Exchangeable cations in the microporous structure and negative electrical charge are two of the properties that allow its application as an adsorbent, for the proper treatment of effluents.

This paper is aimed at identifying the more relevant findings and research gaps on the use of zeolites as adsorbent materials, as well as demonstrating the adsorption mechanisms and particularities of each process, revealing useful information for future research. Review studies, in most cases, bring information about natural or synthetic zeolites, and, in this paper, the reader will find information about both zeolites. A comparison between the two types of zeolites is made, discussing their advantages and disadvantages, their efficiency in wastewater treatment based on their different chemical and physical features, and how the modification of these characteristics can enhance their performance as adsorbents. The next section is dedicated to the discussion about zeolites and their properties, and Section 3 presents a review of several recent studies that used zeolites to remove five classes of contaminants. Finally, Section 4 presents the conclusions, challenges, and future perspectives to zeolite application in wastewater treatment.

\section{Microporous Materials: Zeolites}

2.1. Zeolite Definition. The term zeolite, derived from the Greek words zein (boil) and lithos (rock), was first used to name a mineral that expanded upon being heated, in 1758 by the Swedish mineralogist Alex Fredrick Cronsted [25, 31]. The reason for this peculiar behavior was only revealed in the year 1857, when it was discovered that these materials have a microporous crystalline structure, capable of storing water inside its pores and releasing it if heated, in theoretically infinite cycles of hydration and dehydration. At this time, it was also discovered the presence of compensation cations in zeolite crystalline structures and the ability they have to be removed by other ions in solution, through cation exchange $[25,32]$. Although these properties were important in several industrial sectors, these minerals remained unused for more than 200 years. Its use on an industrial scale only started in 1905, when economically exploitable sedimentary deposits were discovered, which enabled its application in the detergent industry [33]. The first zeolite synthesis was reported in 1948 [25], during the attempt to recreate the hydrothermal conditions of its formation in nature, and the process has been widely studied since then. Currently, 230 species of zeolites are known, categorized into 133 different crystalline structures, according to rules defined by the International Zeolite Association (IZA) [33, 34].

Zeolites belong to the aluminosilicate group, formed by the union of $\mathrm{TO}_{4}$-type tetrahedrons, or basic building units (BBU), where $\mathrm{T}$ represents silicon and/or aluminum atoms (Figure 1(a)). The difference in valence between silicon $(+4)$ and aluminum $(+3)$ leads to an excess of negative charge in the crystalline structure, which is neutralized by the presence of compensation cations, usually elements from alkali metal or alkaline earth metal family [32, 34-38]. The basic structure of zeolites can be described by the generic formula $M_{a / b}\left[\left(\mathrm{AlO}_{2}\right)_{a}\left(\mathrm{SiO}_{2}\right)_{y}\right] \cdot c \mathrm{H}_{2} \mathrm{O}$, where $M$ represents 


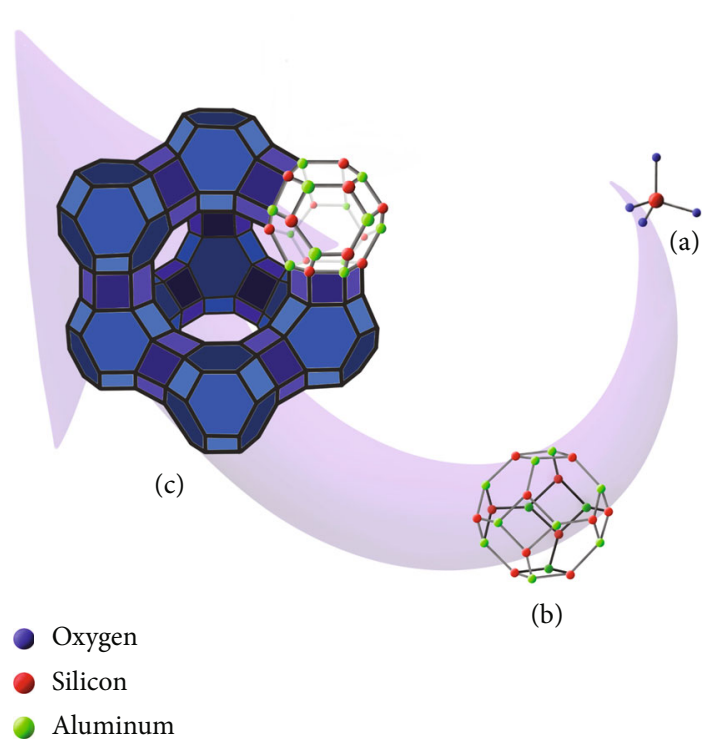

FIgURE 1: Basic building unit (a); composite building units (b) in the crystalline structure of FAU-zeolites (c). Oxygen atoms have been omitted for clarity.

the compensation cation $\left(M=\mathrm{Na}^{+}, \mathrm{K}^{+}, \mathrm{Li}^{+}, \mathrm{Ca}^{2+}, \mathrm{Mg}^{2+}\right.$, etc.) [34]. The variables $a$ and $y$ represent the amount of $\left[\mathrm{SiO}_{4}\right]^{4-}$ and $\left[\mathrm{AlO}_{4}\right]^{5-}$ tetrahedra, and $c$ is the number of water molecules, parameters which vary between the different zeolite crystalline structures. The water molecules and the compensation cation are not part of the chemical composition of zeolites, and these species are free to enter and exit the crystalline structure without causing structural damage to the crystalline structure $[35,39,40]$.

The union of $\left[\mathrm{SiO}_{4}\right]^{4-}$ and $\left[\mathrm{AlO}_{4}\right]^{5-}$ leads to the formation of more complex structures, known as composite building units $(\mathrm{CBU})$, being represented by rings and cages. The rings are named according to the number of oxygen atoms, and rings between 4 and 12 atoms are more common. In the peripheries of the crystal lattice, the rings are called windows and define the effective diameter of the zeolite pores, which limit the entry of certain chemical species into the crystalline structure. This property gives zeolites the ability to be used as molecular sieves and catalysts, in gas separation and the petrochemical industry, respectively. Based on pore diameter, with openings smaller than $20 \AA$, zeolites are classified as microporous materials [25, 38, 41-43]. The union of different types of rings leads to the formation of even more complex structures called cages (Figure 1(b)). The union of the different types of cages leads to the formation of the various zeolite structures [44]. As an example, Figure 1(c) shows the unit cell of a FAU-type zeolite.

Another characteristic of zeolitic materials is the low framework density, which measures the number of $\mathrm{T}$ atoms ( $\mathrm{Si}$ and/or Al) per $1000 \AA^{3}$. Typically, zeolites have a framework density ranging from 5 to 20 , due to the presence of channels and cages in their structure, whereas nonzeolitic materials show values between 20 and 21 [45]. Adsorption is a physical or chemical phenomenon in which molecules accumulate at an interface. This accumulation of molecules is small about the area, and most of the materials used for this purpose are those with a high surface area. Due to their microporous structure, zeolites present a high surface area per volume, being one of the most used materials for the adsorption of liquid and gaseous substances, achieving complete removal of contaminants in effluents, even at low concentrations [46]. Table 1 summarizes natural and synthetic zeolites' main physicochemical and structural characteristics. In general, synthetic zeolites have a lower framework density, due to their higher degree of crystalline ordering, compared to natural zeolites. Consequently, synthetic zeolites have a greater specific surface area, which increases their efficiency as an adsorbent. Ion exchange occurs in zeolites due to the presence of exchangeable cations inside the crystalline structure. Upon contact with an electrolyte solution, the zeolitic cations are removed from the structure and replaced by the solution cations. The amount of exchangeable cations is called cation exchange capacity (CEC), measured in milliequivalents/g, and is dependent on the chemical and physical properties of the material [47].

2.2. Natural Zeolites. Zeolites occur in nature typically filling fractures and pores of volcanic rocks, which limits the formation of large deposits. So, this type of mineral deposit is relatively scarce. Volcanic rocks are the main precursor materials in the formation of zeolites, although other minerals such as feldspars, kaolinite, smectite, volcanic glass, or even other zeolites can fulfill this role, depending on the conditions of pressure, temperature, and presence of mineralizing fluids, in a dissolution-precipitation system [48]. Only a few countries in the world have exploitable zeolite reserves, exploited exclusively using open-pit methods. The processing of zeolitic ore is relatively simple, involving only comminution steps and grading by particle size ranges [49]. Among the 60 varieties of natural zeolites, only clinoptilolite, analcime, heulandite, laumonite, phillipsite, mordenite, chabazite, erionite, and ferrierite have large known sedimentary reserves, located mainly in China [32, 48, 49]. Zeolitic ore reserves have not been estimated as most producing countries do not disclose this information and only their estimated production is available. In terms of production, the leading countries in 2019 were China $(320.000 \mathrm{t})$, Korea $(150.000 \mathrm{t})$, Slovakia $(120.000 \mathrm{t})$, New Zealand $(100.000 \mathrm{t})$, and the United States (98.000 t) [50]. Natural zeolites, unlike synthetic ones, exhibit a wide range of mineralogical and chemical composition, crystal structure, and pore sizes, which restrain their application if more homogeneous properties are required to guarantee high efficiency. Nevertheless, natural zeolites present a lower cost than synthetic zeolites, ensuring their application in animal feed production, water treatment, odor control, gas adsorption, and pozzolanic addition to Portland cement [51].

2.3. Synthetic Zeolites. Crystalline solids can be synthesized using two approaches, whose chemical reactions occur in the solid state or the liquid state. The first class of reactions occurs slowly at relatively high temperatures, above $300^{\circ} \mathrm{C}$. In the liquid state, chemical species have greater freedom of movement, and the reaction occurs faster and at lower temperatures $[35,38,52]$. Zeolite synthesis occurs in a liquid 


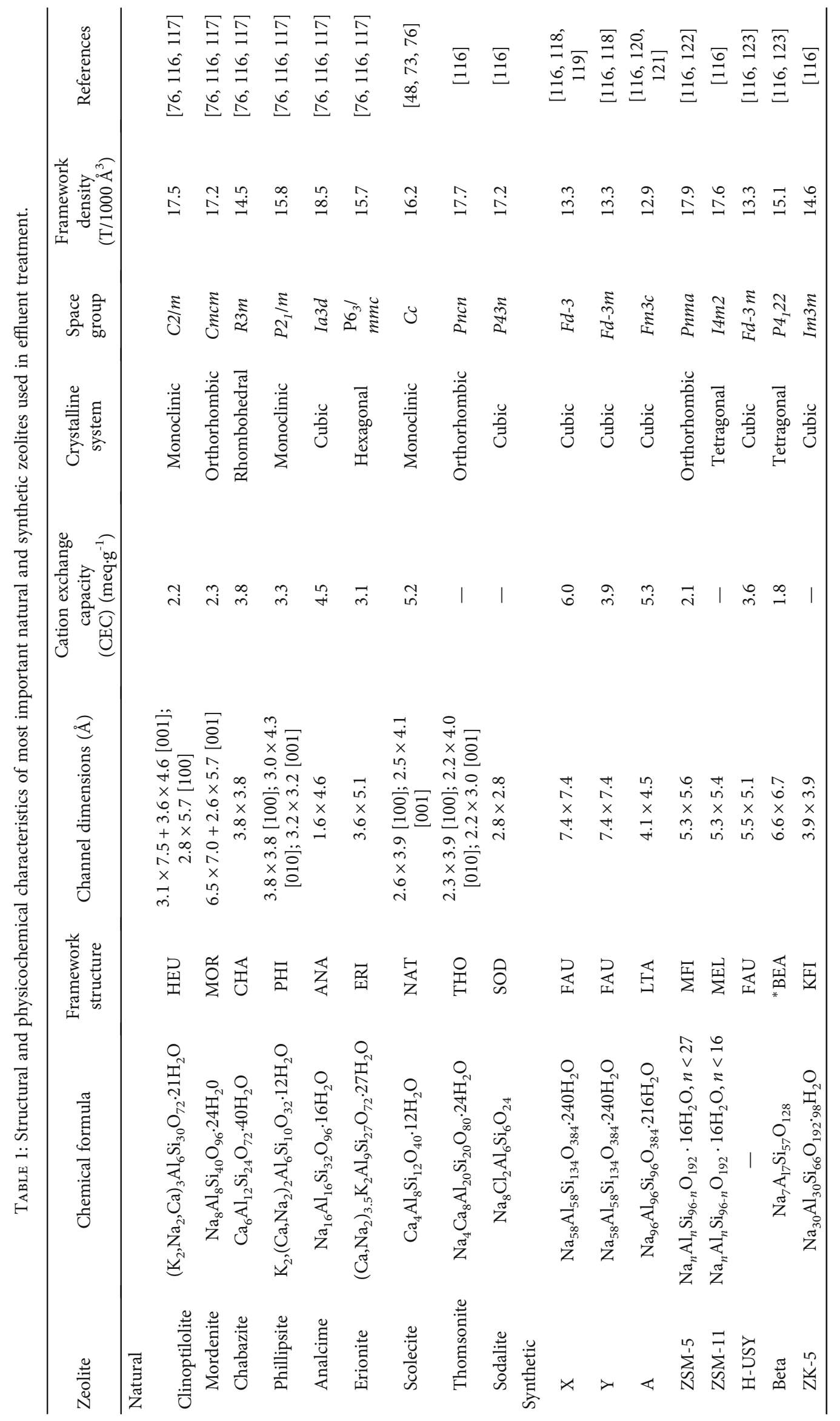




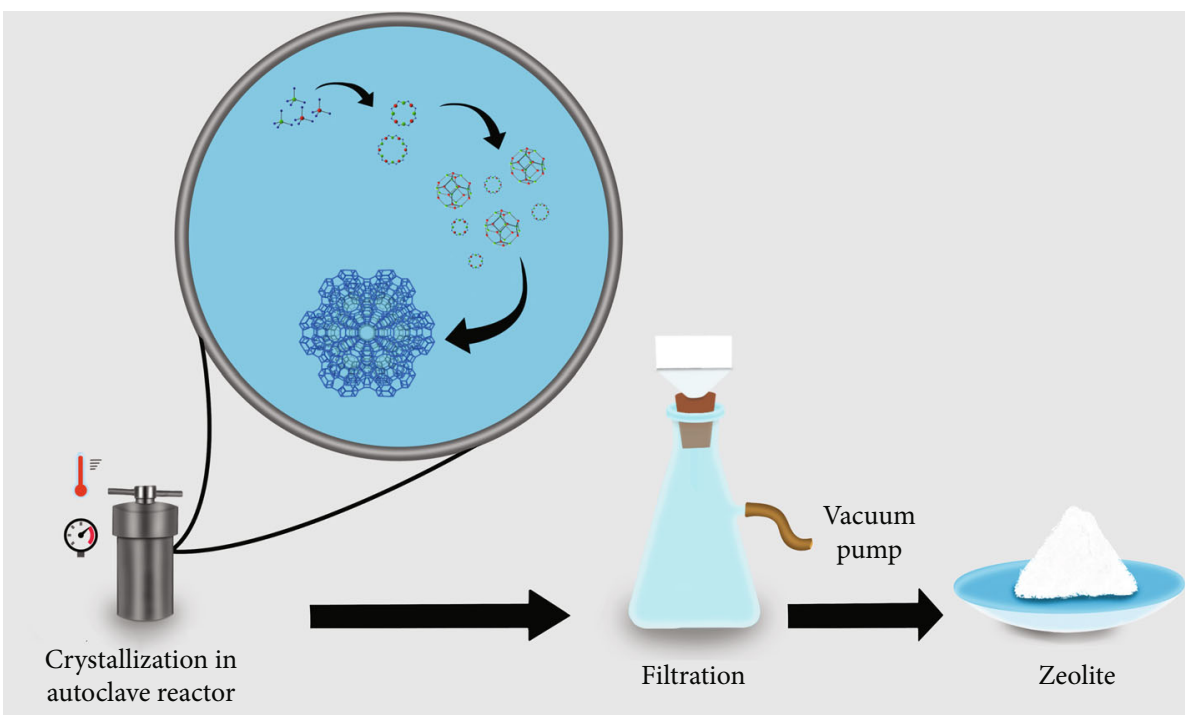

(a)

(b)

(c)

FIGURE 2: Hydrothermal synthesis process. The crystallization occurs in an autoclave (a). Then, the product is filtered and oven dried (b). The remaining solid is the zeolite (c).

state, and several methods can be applied, the main one being the hydrothermal method, considered one of the least costly methods. In the process, water is used as a solvent, along with the sources of silicon and aluminum. Other reagents involved in the process are the mineralizing agent $\left(\mathrm{OH}^{-}, \mathrm{F}^{-}\right)$, metal cations, and structure-directing agent (usually an organic surfactant) [53]. Figure 2 illustrates the hydrothermal synthesis process. The reaction takes place in an autoclave reactor under high temperature and autogenous pressure (often up to 15 bar). The reaction product is then washed several times, filtered, and oven dried. The solid obtained is the zeolite, which can be used for a variety of applications. The temperature and time for crystallization are critical parameters for synthesis and are dependent on the zeolite to be synthesized [52]. However, the method has some disadvantages, which may limit its application. The water consumption is high, which at the end of the process generates alkaline wastewater, which is difficult to manage. Besides, the processes may require long reaction times. With advances in zeolite synthesis studies, several other methods were developed, such as nonaqueous methods (solvothermal and ionothermal synthesis, whose solvent is replacing alcohol or hydrocarbons and ionic solutions, respectively), microwave radiation methods, sol-gel methods, and ultrasound energy method. Each process has its advantages and disadvantages, and specific types of zeolite crystalline structures can only be synthesized by a certain method, which becomes a limiting factor $[35,38,53,54]$.

The synthesis of zeolites using $\mathrm{SiO}_{2}$ and $\mathrm{Al}_{2} \mathrm{O}_{3}$ from chemical reagents is an expensive process due to the cost of manufacturing and purchasing. For this reason, the number of researches focused on locating alternative sources of silica and alumina from cheaper and abundant sources increased in the last decades [35]. Several materials, including those considered waste, have already been successfully used for this purpose. To be used as a precursor, the residue must be cheap, readily available, generated in large quantities, and rich in silica and/or alumina, with low content of contaminating elements [55]. Table 2 shows a few of the most common waste materials used in zeolite synthesis. On the other hand, the quality of these materials is very unstable, which can compromise the quality of the synthesis, requiring a process optimization step [56]. Despite their higher cost, synthetic zeolites have the advantage of presenting uniform properties, which can guarantee their application in processes that require materials with high purity. Among the properties of synthetic zeolites, the pore size distribution is an important feature to characterize this material. As shown in Table 1, natural zeolites generally present pores with smaller diameters, in addition to varying opening dimensions, depending on the crystallographic direction. On the other hand, a major characteristic of synthetic zeolites is their larger pore diameter and their uniformity, regardless of the crystallographic direction, which consequently increases their efficiency in certain applications.

Despite advances in the field of zeolite synthesis, the nucleation and crystallization mechanisms are still not deeply understood. A full understanding of this field can lead to the synthesis of new crystalline structures, which can further expand the field of application of these materials. Further developments in the field of synthesis methods are also needed, to reduce the cost of production and bring economic benefits to large-scale production [55].

2.4. Zeolite Modification. The effectiveness of zeolite application in certain processes depends directly on their physicochemical and structural properties. In wastewater treatment, the zeolites which present negative electrical charge and compensation cations in their crystal structure ensure the removal of cationic species but can be incompatible with the removal of anionic species and organic compounds. Thus, the modification of zeolites enables the 
TABLE 2: Common low-cost waste materials used in zeolite synthesis.

\begin{tabular}{|c|c|c|c|c|}
\hline Waste material & $\begin{array}{r}\mathrm{O} \\
\text { pro } \\
\mathrm{SiO}_{2} \\
\end{array}$ & $\begin{array}{l}\text { xide } \\
\text { vided } \\
\mathrm{Al}_{2} \mathrm{O}_{3}\end{array}$ & Zeolite & References \\
\hline Kaolin/metakaolin & $\checkmark$ & $\checkmark$ & A, Y, 13X, ZSM-5 & {$[31,121,124-131]$} \\
\hline Glass powder & $\checkmark$ & & A, sodalite, LOS-type zeolite, MEL-type zeolite, X, Na-P1, analcime & {$[132-136]$} \\
\hline Aluminum waste & & $\checkmark$ & $13 \mathrm{X}$, analcime, sodalite, $\mathrm{A}$ & {$[137,138]$} \\
\hline Coal fly ash & $\checkmark$ & $\checkmark$ & $\mathrm{X}, \mathrm{A}$, sodalite, $4 \mathrm{~A}, \mathrm{Na}-\mathrm{P} 1$, phillipsite, thomsonite, $\mathrm{Y}$ & {$[139-145]$} \\
\hline Fumed silica & $\checkmark$ & & A, Na-P & {$[146,147]$} \\
\hline Red mud & & $\checkmark$ & FAU-type zeolite, GIS-type zeolite, magnetic 4A, A, X, ZK-5 & {$[56,148,149]$} \\
\hline Oil shale ash & $\checkmark$ & $\checkmark$ & $\mathrm{X}, \mathrm{A}$ & {$[118,150]$} \\
\hline Bauxite residue & & $\checkmark$ & $\mathrm{X}, \mathrm{A}, \mathrm{P}$ & {$[151,152,172]$} \\
\hline Electrolytic manganese residue & $\checkmark$ & $\checkmark$ & P, A, chabazite & {$[153]$} \\
\hline Diatomite & $\checkmark$ & $\checkmark$ & $\mathrm{X}, \mathrm{Y}$ & {$[85,154,155]$} \\
\hline Rice husk ash & $\checkmark$ & & A, ZSM-5, X & {$[15,156-158,173]$} \\
\hline
\end{tabular}

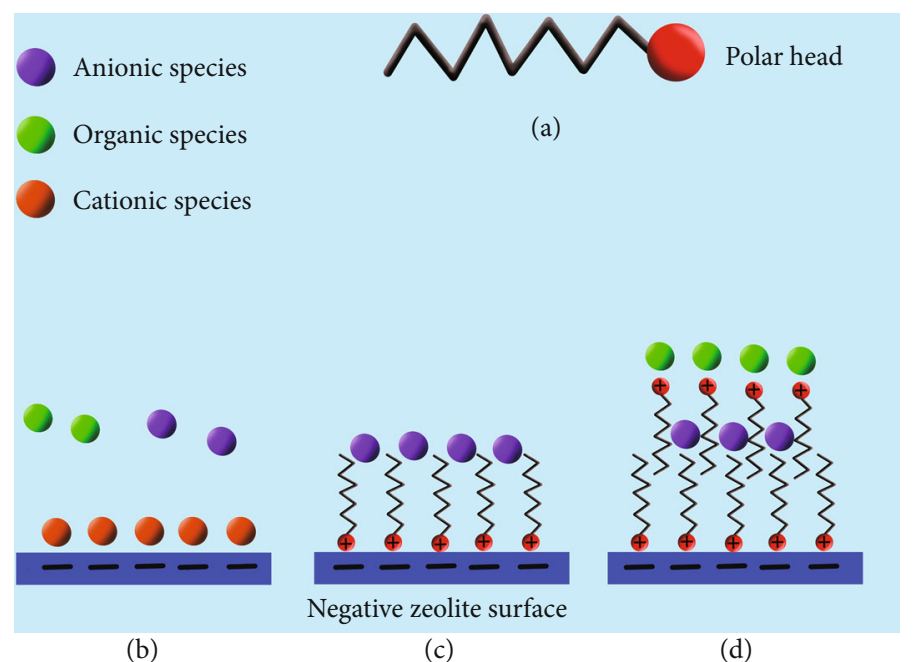

FIGURE 3: Zeolite can only adsorb cationic species (b). When modified by a cationic surfactant (a), zeolite can also remove anionic (c) and organic species or both $(\mathrm{d})$.

removal of these compounds, in addition to increasing the removal efficiency of cationic species by natural zeolites. Due to the different geological conditions in which zeolites crystallize in nature, the presence of more than one type of compensation cation is common. Modification with a solution of inorganic salts $\left(\mathrm{NaCl}, \mathrm{CaCl}, \mathrm{NH}_{4} \mathrm{Cl}\right.$, among others) contributes to uniform the compensation cations present in the crystal structure. Since each cation can be exchanged at different levels of selectivity, standardization leads to optimization of the cation exchange capacity [57].

Another type of modification that has been extensively studied recently is surfactant modification. These chemical species (Figure 3(a)) are described by having a polar head (ionic or neutral) and a nonpolar tail, composed basically of hydrocarbons. Among cationic surfactants used in the modification of zeolites to remove organic compounds, tetramethylammonium, cetyltrimethylammonium (CTMA), hexadecyltrimethylammonium (HDTMA), octadecyldimethylbenzyl ammonium (ODMBA), n-cetylpyridinium
(CPD), benzyl tetradecyl ammonium (BDTDA), and stearyldimethylbenzylammonium (SDBAC) are the most commonly used [58]. As illustrated in Figure 3(b), unmodified zeolites can electrostatically attract only the cationic species in the solution. When modifying the zeolite with a cationic surfactant, below the critical micellar concentration (CMC), a surfactant monolayer is formed on the zeolite surface, in which the nonpolar tails are directed towards the bulk solution, and attracts the organic species through hydrophobic interactions (Figure 3(c)). When surpassing the CMC, a surfactant bilayer is formed, which results in the reversal of the electrical charge of the zeolite surface. Under these conditions, anions in the solution can be removed, as well as organic compounds that can still interact with the hydrophobic regions (Figure 3(d)) [59].

2.5. Zeolite Characterization for Water Treatment. The characterization of any material is of great importance for the knowledge of its physical and chemical characteristics and 
the prediction of its behavior during its application. In the case of zeolites for the treatment of effluents, some characterization techniques are especially relevant.

The identification of the zeolitic phases can be performed using X-ray Diffraction (XRD), which is the most used technique for this purpose. In addition to the identification of phases and the quantification by the Rietveld method (particularly in the case of natural zeolites, which present other contaminating minerals), it is also possible to determine their degree of crystallinity (in synthetic zeolites, the presence of noncrystalline material remaining after synthesis negatively affects the material's adsorption capacity) [60].

As mentioned in Section 2.1, adsorption is a phenomenon that is surface area-dependent. Furthermore, pore size also affects the efficiency and selectivity for adsorption of molecules and ions by intraparticle diffusion. Such parameters can be determined using gas adsorption-desorption techniques with the aid of the Brunauer-Emmett-Teller (BET) model, to determine the specific surface area, and Barrett-Joyner-Halenda (BJH) model, to determine the relative distribution of pore sizes. Once defined, these parameters are used to select the best zeolite to remove a particular contaminant [61].

In the case of removal of organic contaminants, the regeneration of zeolite by temperature is possible, enabling the reuse of the material, which can bring economic benefits to the process. The thermogravimetry (TG) and differential thermal analysis (DTA) techniques help detect the maximum temperature to which the zeolite can be subjected without the destruction of its crystalline structure, with a consequent reduction in its potential for removing contaminants, thus contributing to the optimization of the regeneration process [61].

Another technique that is relevant in the characterization of zeolite for effluent treatment is the determination of the material's surface electrical properties (zeta potential). Since the electrical charge of zeolites can be modified by changing the $\mathrm{pH}$, the determination of the point of zero charge $\left(\mathrm{pH}_{\mathrm{PZC}}\right)$ at which the reversal of electrical charge occurs contributes especially in the removal of anionic contaminants, in which it is possible to make the surface positively charged by proper $\mathrm{pH}$ adjustment [62].

Finally, the determination of the cation exchange capacity (CEC) must be determined, to estimate the amount of contaminant per unit of mass a given zeolite is capable of removing, which implies defining the optimal amount of zeolite for a given process [63]. Although there are other characterization techniques necessary for other applications, the abovementioned are of greater relevance in the use of zeolites for the treatment of effluents.

\section{Application of Zeolites in Wastewater Treatment}

The quality of industrial effluents has received increased attention due to the concern with environmental impacts in the industrial sector. In this context, an efficient collection and treatment system becomes necessary, as incorrect disposal of water has the potential to cause a series of liabilities to the environment $[6,64-71]$. Besides, there is great pressure from environmental policies for the reuse of effluent, to reduce the intake of new water and preserve natural resources [72]. Due to their cationic exchange negative charge characteristics and relatively low synthesis cost, zeolites have great potential to be used in the removal of a wide variety of substances, such as heavy metals, organic compounds, dyes, and pigments, reagents, nitrogen compounds, among others [58].

\subsection{Inorganic Compound Removal}

3.1.1. Heavy Metals. The application of zeolites for heavy metal sequestration in effluent treatment has found the largest applicability with synthetic zeolites, followed by modified zeolites. Natural varieties, although quite attractive from an economic point of view, show the lowest metal sorption for most heavy metals, as presented in Table 3 , because the mineralogical composition of natural zeolites varies greatly from one region to another and even within the same mineral deposit [49]. In addition, in many cases, more than one variety of zeolite is found in the ore, along with several other minerals which act as contaminants, since they have low metal sorption capacity. Among the contaminating minerals, quartz, albite, biotite, illite, montmorillonite, feldspar, calcite, halite, and heulandite are commonly observed [73-75]. Synthetic zeolites, constituted in most cases by a single phase, are adsorbents with high uniformity in their properties, such as pore size distribution, hydrophobicity/ hydrophilicity, and the presence of a single compensation cation. The combination of these parameters guarantees their greater capacity for cation exchange compared to natural zeolites.

The modification of natural zeolites concerns a series of chemical treatments that are aimed at intensifying their properties. Chemical treatments, with acids and/or bases, lead to the removal of impurities that clog the pores, resulting in increased cation exchange capacity [58]. Another way of modifying zeolites is by using organic surfactants, which form a monolayer at the zeolite surface. Quaternary amines are the most widely used reagents for this purpose and, as cationic reagents, give the zeolites the ability to adsorb anions [76]. In Table 3, it can be observed that modified clinoptilolite demonstrated intermediate adsorption capacity between its natural and synthetic forms. The use of hexadecyl pyridinium bromide (a surfactant with the cationic site) in the modification of clinoptilolite enabled the removal of chromium, in the $\mathrm{CrO}_{4}^{2-}$ form, something that would not be possible with natural or synthetic zeolites [77]. Another heavy metal that is present in the form of anions in solution is arsenic. At $\mathrm{pH}$ values above 2 , this element is found in the forms $\mathrm{HAsO}_{4}{ }^{2-}, \mathrm{H}_{2} \mathrm{AsO}_{4}{ }^{-}$, and $\mathrm{AsO}_{4}{ }^{3-}$, and its removal is only possible with the use of modified zeolites. In a study using clinoptilolite coated with iron oxide, the removal of arsenic in the anionic solution was possible, due to its affinity for the iron oxide sites at the zeolite surface [78].

Adsorption processes that use zeolites as adsorbents are strongly affected by changes in $\mathrm{pH}$, temperature, and adsorbent/solution mass ratio. When the attractive forces between 


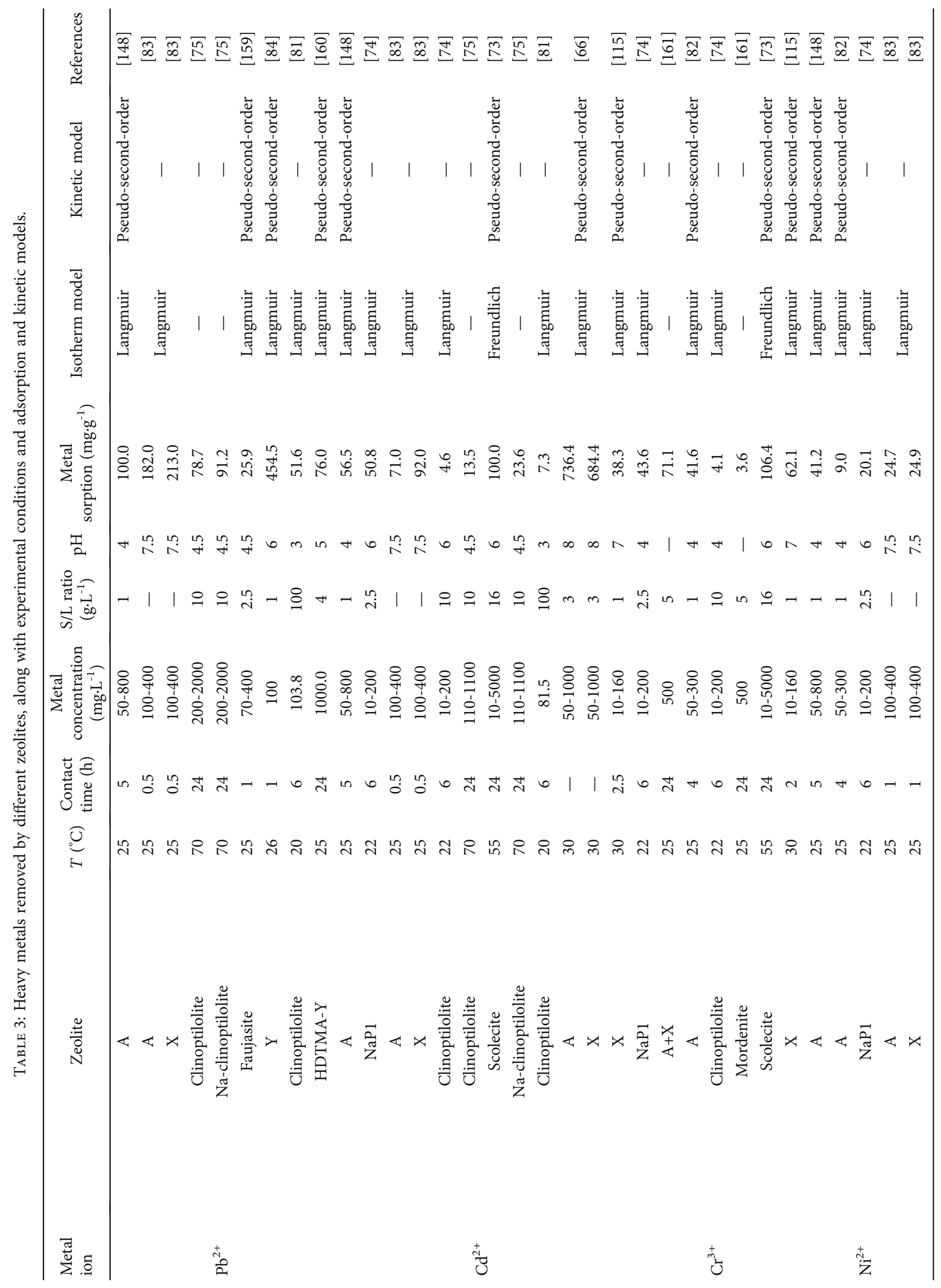




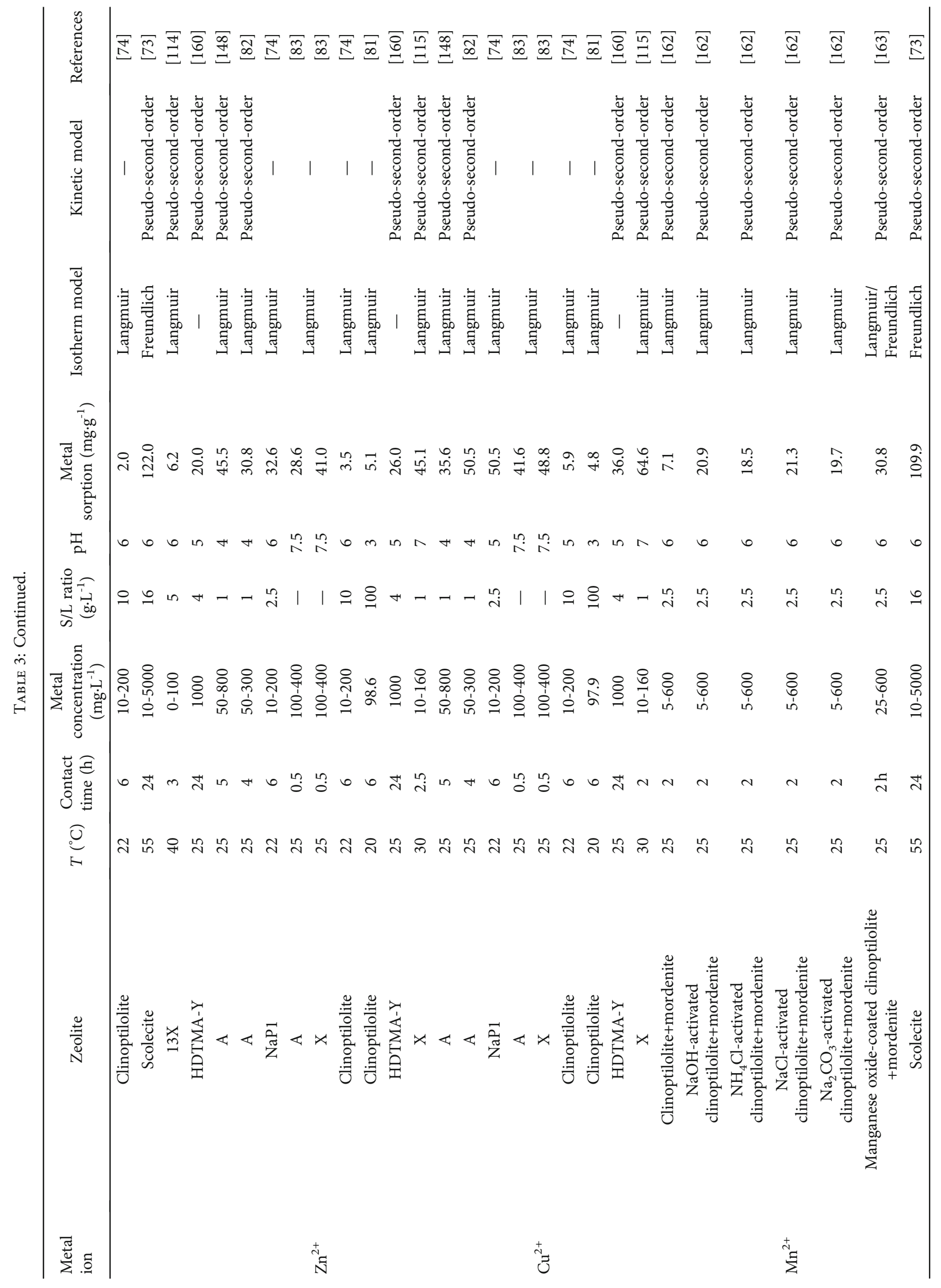




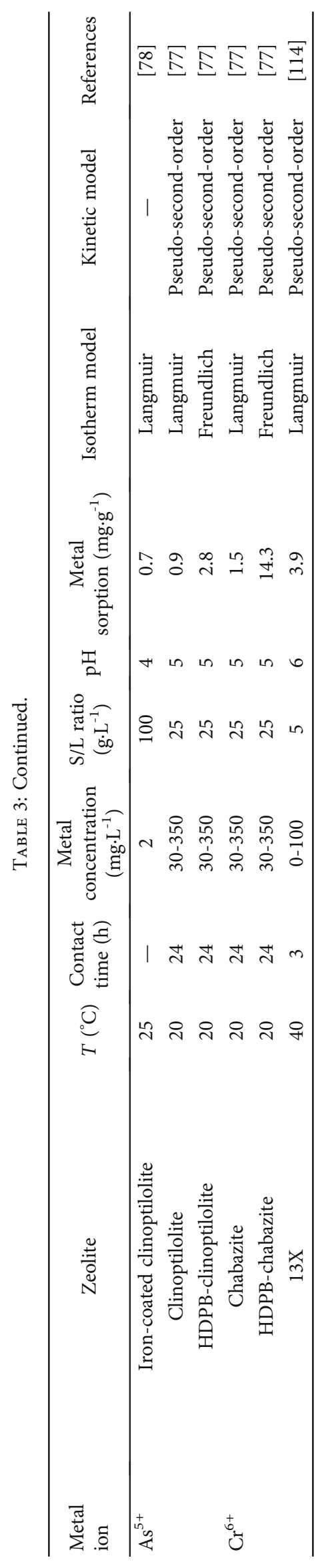


the surface and the adsorbate overcome the attraction between the adsorbate and the solvent, the ions start to concentrate on the zeolite surface. As a rule, the zeolite metal adsorption process occurs in an endothermic and spontaneous process, presenting higher rates of adsorption with increased temperature [79]. This fact was proved by Dal Bosco et al. [73], who carried out adsorption tests with $\mathrm{Cr}^{2+}, \mathrm{Ni}^{2+}, \mathrm{Cd}^{2+}$, and $\mathrm{Mn}^{2+}$ in zeolite scolecite, at temperatures of 25,40 , and $60^{\circ} \mathrm{C}$. The authors reported greater adsorption of all metals in tests performed at $60^{\circ} \mathrm{C}$, followed by those performed at 40 and $25^{\circ} \mathrm{C}$. In similar experiments, Curković et al. [75] analyzed the use of natural clinoptilolite to remove $\mathrm{Pb}^{2+}$ and $\mathrm{Cd}^{2+}$ at different temperatures (20$70^{\circ} \mathrm{C}$ ). The results also indicated that the increase in temperature favors the adsorption rate in all analyzed scenarios.

The variation in $\mathrm{pH}$ also strongly affects the metal adsorption capacity of zeolites. In highly alkaline environments, it can be observed that the formation of metal oxides and hydroxides as a precipitated form reduces the availability of ions to be adsorbed, thus reducing the adsorption rate. In highly acidic environments, the presence of an abundant amount of $\mathrm{H}^{+}$in the solution impairs the adsorption due to competition between this chemical species and the metal to be adsorbed, which also reduces the adsorption rate, as verified by Zanin et al. [80]. The authors evaluated the removal of $\mathrm{Cr}^{3+}, \mathrm{Cu}^{2+}$, and $\mathrm{Fe}^{3+}$ using clinoptilolite, in solutions with $\mathrm{pH} 3,4$, and 5. For chromium, the removal rate was greater at $\mathrm{pH}$, with the lowest value observed at $\mathrm{pH} 3$. As for copper and iron, adsorption reached its maximum at $\mathrm{pH} 4$, being slightly lower at $\mathrm{pH} 5$. In solutions with $\mathrm{pH} 3,4$, and 5, Dal Bosco et al. [73] demonstrated that the adsorption density of $\mathrm{Cd}^{2+}, \mathrm{Mn}^{2+}$, and $\mathrm{Cr}^{3+}$ in zeolite scolecite increased progressively with the increase in $\mathrm{pH}$, whereas for $\mathrm{Ni}^{2+}$, the adsorption rate increased rapidly from $\mathrm{pH} 3$ to 4 but showed a significant increase in the transition to $\mathrm{pH} 5$. In a similar study, Alvarez-Ayuso et al. [74] varied the $\mathrm{pH}$ to values of $3,4,5$, and 6 , in the analysis with $\mathrm{Zn}^{2+}, \mathrm{Cd}^{2+}, \mathrm{Cu}^{2+}, \mathrm{Ni}^{2+}$, and $\mathrm{Cr}^{3+}$ using $\mathrm{NaP1}$ zeolite. The $\mathrm{Zn}^{2+}$ adsorption values increased with increasing $\mathrm{pH}$, whereas $\mathrm{Cd}^{2+}, \mathrm{Cu}^{2+}$, and $\mathrm{Ni}^{2+}$ showed a slight increase in the transition from $\mathrm{pH} 3$ to 4 , stabilizing above that value. As for $\mathrm{Cr}^{3+}$, the adsorption increased significantly from $\mathrm{pH} 3$ to 4 , again sharply reducing from $\mathrm{pH} 5$ to 6 . It is evident the fundamental role of $\mathrm{pH}$ in the adsorption of metals in zeolites, as this governs the metal speciation in solution. Preliminary studies of the effect on the solution's $\mathrm{pH}$ are needed to evaluate the removal efficiency, especially when the system is multielement, as each metal has specific $\mathrm{pH}$ values at which certain compounds form and precipitate [81]. The $\mathrm{pH}$ conditions most used in the application of zeolite in heavy metal removal are close to neutrality or slightly acidic, as can be seen in Table 3.

The solid-liquid ratio is also an important experimental variable when investigating metal adsorption in zeolites. The changes in this parameter can directly or indirectly affect other variables, such as the $\mathrm{pH}$ and the solution chemical composition [79]. The increased number of particles raises the specific surface area available for adsorption to occur. In addition, the friction between the particles is more intense than in systems with lower solid percentages. As the particles break down, further increasing the available surface area, greater metal removal can be achieved [79]. It is expected that the adsorption rate will increase with dosage; however, this is not always observed. The high zeolite dosage also increases the amount of the compensation cations in the solution, which can compete with the heavy metal to be removed, leading to a reduction in the adsorption rate [79].

In heavy metal adsorption systems, it is important to consider the presence of more than one species in the solution. In a mixture of heavy metal ions, the increase in the initial concentration leads to a reduction in the adsorption of certain species, due to the greater selectivity presented by some species. Table 4 presents sequences of selectivity for the adsorption of metals in different zeolites, synthetic and natural. Several factors govern the selectivity for metal ions, which must be considered in each system investigated. Among them, it can be cited the microporous structure and the properties of the element to be removed, such as the ionic radii, hydrated ionic radii, and free hydration energy [82]. As an example, it is noticed the greater ease that lead presents of being adsorbed by zeolites. Among the metals investigated, lead presents the lowest atomic radius when surrounded by water molecules and the lowest hydration energy, which expresses the difficulty to lose the water molecules that surround the ion [82]. Therefore, the metal shows great facility to become a dehydrated ion. Although its dehydrated atomic radius is larger, the other ions tend to remain in hydrated form, which makes the penetration of dehydrated lead ions into the zeolite structure more likely, explaining that the greater selectivity in the removal of this metal is present [81].

The adsorption is strongly dependent on factors such as solution $\mathrm{pH}$, temperature, adsorbent dosage, and solution initial concentration. Since these factors varied in the studies analyzed (Table 3), it is difficult to compare the performance of different zeolites. However, in a study verifying the adsorption of a mixture of heavy metals using zeolites A and $\mathrm{X}$, in the same experimental conditions, Ibrahim et al. [83] observed greater efficiency in removal using phase $\mathrm{X}$, since this crystalline structure has larger pores $(7.4 \AA)$, compared to phase A ( $4.5 \AA)$. In a similar study, Shariatinia and Bagherpour [84] also noticed a higher affinity of lead for zeolite NaY (7.4 $\AA$ ) compared to zeolite NaP1 (which has different windows depending on the crystallographic directions: $3.1 \times 4.5 \AA$ [85], $2.8 \times 4.8 \AA$ [010]). Smaller pores, of dimensions close to those of hydrated ions, limit their entry and impair the diffusion process within the crystalline structure, which compromises the performance of a particular zeolitic phase as an adsorbent.

3.1.2. Nitrogen Compounds. As seen in Table 5, zeolites show great potential for application in ammonia removal from effluents. The synthetic versions, due to their larger pore sizes, have a greater affinity for the ammonia molecules (mean diameter of $0.283 \mathrm{~nm}$ ), which facilitates their entry into the zeolite crystalline structure [86]. Temperature also plays an important role in the removal of ammonia by zeolite, with a reduction in the amount of ammonia removed as 
TABLE 4: Selectivity in competitive adsorption of heavy metals by different zeolites.

\begin{tabular}{|c|c|c|c|c|c|c|c|}
\hline \multicolumn{3}{|c|}{ Adsorption selectivity } & \multicolumn{5}{|c|}{ Ionic properties } \\
\hline Zeolite & Selectivity & References & $\begin{array}{l}\text { Heavy } \\
\text { metal }\end{array}$ & $\begin{array}{l}\text { Hydrated } \\
\text { radius }(\AA)\end{array}$ & $\begin{array}{l}\text { Unhydrated } \\
\text { radius }(\AA)\end{array}$ & $\begin{array}{c}\text { Free energy of } \\
\text { hydration }\left(\mathrm{kJ} \cdot \mathrm{mol}^{-1}\right)\end{array}$ & References \\
\hline FAU-type & $\mathrm{Pb}^{2+}>\mathrm{Cu}^{2+}>\mathrm{Cd}^{2+}>\mathrm{Zn}^{2+}>\mathrm{Co}^{2+}$ & [164] & $\mathrm{Pb}$ & 4.01 & 1.32 & -1425 & \\
\hline A & $\mathrm{Cu}^{2+}>\mathrm{Cr}^{3+}>\mathrm{Zn}^{2+}>\mathrm{Co}^{2+}>\mathrm{Ni}^{2+}$ & {$[82]$} & $\mathrm{Cu}$ & 4.19 & 0.72 & -2010 & \\
\hline A & $\mathrm{Pb}^{2+}>\mathrm{Cd}^{2+}>\mathrm{Cu}^{2+}>\mathrm{Zn}^{2+}>\mathrm{Ni}^{2+}$ & [83] & $\mathrm{Cd}$ & 4.26 & 0.97 & -1755 & \\
\hline A & $\mathrm{Pb}^{2+}>\mathrm{Cd}^{2+}>\mathrm{Zn}^{2+}>\mathrm{Ni}^{2+}>\mathrm{Cu}^{2+}$ & [148] & $\mathrm{Zn}$ & 4.30 & 0.74 & -1955 & \\
\hline $\mathrm{NaP} 1$ & $\mathrm{Cr}^{3+}>\mathrm{Cu}^{2+}>\mathrm{Zn}^{2+}>\mathrm{Cd}^{2+}>\mathrm{Ni}^{2+}$ & {$[74]$} & Co & 4.23 & 0.72 & -1915 & {$[165,166]$} \\
\hline $\mathrm{X}$ & $\mathrm{Pb}^{2+}>\mathrm{Cd}^{2+}>\mathrm{Cu}^{2+}>\mathrm{Zn}^{2+}>\mathrm{Ni}^{2+}$ & [83] & $\mathrm{Cr}$ & 4.61 & 0.64 & -4010 & \\
\hline $\mathrm{X}$ & $\mathrm{Cr}^{3+}>\mathrm{Cu}^{2+}>\mathrm{Cd}^{2+}>\mathrm{Zn}^{2+}$ & [115] & $\mathrm{Ni}$ & 4.04 & 0.70 & -1980 & \\
\hline Scolecite & $\mathrm{Cr}^{3+}>\mathrm{Mn}^{2+}>\mathrm{Cd}^{2+}>\mathrm{Ni}^{2+}$ & {$[73]$} & $\mathrm{Mn}$ & 4.38 & 0.80 & -1760 & \\
\hline Clinoptilolite & $\mathrm{Pb}^{2+}>\mathrm{Zn}^{2+}>\mathrm{Cu}^{2+}>\mathrm{Cd}^{2+}$ & [81] & & & & & \\
\hline Clinoptilolite & $\mathrm{Cu}^{2+}>\mathrm{Cr}^{3+}>\mathrm{Zn}^{2+}>\mathrm{Cd}^{2+}>\mathrm{Ni}^{2+}$ & [74] & & & & & \\
\hline
\end{tabular}

TABLE 5: Zeolites used in ammonium removal, along with experimental conditions and adsorption and kinetic models.

\begin{tabular}{|c|c|c|c|c|c|c|c|c|c|}
\hline Zeolite & $\begin{array}{c}T \\
\left({ }^{\circ} \mathrm{C}\right)\end{array}$ & $\begin{array}{l}\text { Contact } \\
\text { time }(\mathrm{h})\end{array}$ & $\begin{array}{c}\text { Concentration } \\
\left(\mathrm{mg} \cdot \mathrm{L}^{-1}\right)\end{array}$ & $\begin{array}{l}\mathrm{S} / \mathrm{L} \text { ratio } \\
\left(\mathrm{g} \cdot \mathrm{L}^{-1}\right)\end{array}$ & $\mathrm{pH}$ & $\begin{array}{l}\mathrm{NH}_{4}^{+} \text {sorption } \\
\text { capacity }\left(\mathrm{mg} \cdot \mathrm{L}^{-1}\right)\end{array}$ & $\begin{array}{l}\text { Isotherm } \\
\text { model }\end{array}$ & Kinetic model & References \\
\hline Clinoptilolite & 25 & 12 & $1-20$ & $0-0.6$ & - & 4.3 & Langmuir & $\begin{array}{l}\text { Pseudo-first- } \\
\text { order }\end{array}$ & \multirow{2}{*}{ [89] } \\
\hline $\begin{array}{l}\mathrm{NaNO}_{3} \text {-modified } \\
\text { clinoptilolite }\end{array}$ & 25 & 12 & $1-20$ & $0-0.6$ & - & 8.1 & Freundlich & $\begin{array}{l}\text { Pseudo-first- } \\
\text { order }\end{array}$ & \\
\hline Zeolite $\mathrm{P}+$ analcime & 25 & 1 & $5-500$ & 5 & 6 & 17.5 & $\begin{array}{l}\text { Koble- } \\
\text { Corrigan }\end{array}$ & $\begin{array}{c}\text { Pseudo- } \\
\text { second-order }\end{array}$ & {$[90]$} \\
\hline $\begin{array}{l}\text { Zeolite X } \\
\text { Zeolite A }\end{array}$ & 25 & 8 & $100-400$ & 2 & 7 & $\begin{array}{l}89.1 \\
59.3\end{array}$ & Freundlich & $\begin{array}{c}\text { Pseudo- } \\
\text { second-order }\end{array}$ & {$[86]$} \\
\hline Chabazite & 25 & 5 & $130-2080$ & 75 & 7 & 39.3 & Langmuir & $\begin{array}{l}\text { Pseudo- } \\
\text { second-order }\end{array}$ & {$[91]$} \\
\hline Zeolite NaY & 25 & 2 & $40-615$ & 6.3 & - & 26.5 & Langmuir & $\begin{array}{l}\text { Pseudo- } \\
\text { second-order }\end{array}$ & {$[4]$} \\
\hline $\begin{array}{l}\text { Modified Na- } \\
\text { clinoptilolite }\end{array}$ & 25 & 24 & $0-83$ & - & 7.2 & 14.5 & Langmuir & - & {$[167]$} \\
\hline $\begin{array}{l}\text { Clinoptilolite } \\
\text { +mordenite }\end{array}$ & 25 & 8 & $5-120$ & 10 & 6 & 6.3 & Freundlich & $\begin{array}{l}\text { Pseudo- } \\
\text { second-order }\end{array}$ & {$[88]$} \\
\hline Zeolite $\mathrm{NaA}$ & & & & & & 10.5 & & & \\
\hline $\begin{array}{l}\text { Magnetic zeolite } \\
\mathrm{NaA}\end{array}$ & 25 & $0-2$ & - & - & 7.9 & 10.4 & Freundlich & second-order & [87] \\
\hline
\end{tabular}

the temperature increases, due to the desorption of ammonia from the surface [87]. In contrast, Widiastuti et al. [88] demonstrate in their studies that the increase in temperature increases the amount of ammonia adsorbed. These results indicate that the influence of temperature on ammonia adsorption onto zeolites is yet not well understood. Despite the importance of temperature in adsorption processes, this variable has not been thoroughly investigated, and further studies are needed to conclude its influence on the ammonia-zeolite adsorption system.

Solution pH strongly affects the adsorption process as well. At very low $\mathrm{pH}$ values, competition between $\mathrm{H}^{+}$ions makes it difficult to adsorb ammonia molecules, reducing the sorption capacity. In alkaline solutions, $\mathrm{NH}_{4}^{+}$converts to $\mathrm{NH}_{3}$, which also reduces the adsorption rate, due to the elimination of electrostatic attraction forces between adsorbate and adsorbent. In a study analyzing ammonia adsorption in $\mathrm{pH}$ between 4 and 10, Fu et al. [89] observed that the greatest removal of $\mathrm{NH}_{4}{ }^{+}$with a natural clinoptilolite occurs at $\mathrm{pH} 5-8$. In adsorption tests carried out in the $\mathrm{pH}$ range between 2 and 11, Zhao et al. [90] verified that maximum removal of ammonia by a mixture of zeolite $\mathrm{P}$ and analcime, synthesized from red mud, occurs at $\mathrm{pH}$ 6. In a study analyzing the removal of ammonia by synthetic zeolites, $\mathrm{A}$ and $\mathrm{X}$ in the $\mathrm{pH}$ range between 2 and 10, Moussavi et al. [86] demonstrated that the optimum value for the removal of ammonia occurs at $\mathrm{pH} 7$. These results indicate the importance that this variable presents in the removal of ammonia using zeolite as adsorbents and that the best results can be obtained at $\mathrm{pH}$ close to neutrality.

Another factor to be considered in ammonia removal using zeolites is the competition with other ions in the solution. The ionic species readily penetrate the zeolite pores, 
being easily adsorbed in comparison with molecules. $\mathrm{Fu}$ et al. [89] analyzed the removal of ammonia using clinoptilolite and clinoptilolite modified with $\mathrm{NaNO}_{3}$ and found that the presence of $\mathrm{Na}^{+}, \mathrm{K}^{+}, \mathrm{Mg}^{2+}, \mathrm{NO}_{3}{ }^{-}, \mathrm{SO}_{4}{ }^{2-}$, and $\mathrm{Cl}^{-}$negatively affected the $\mathrm{NH}_{4}{ }^{+}$adsorption rate. Zhao et al. [90] verified that the removal of $\mathrm{NH}_{4}^{+}$undergoes a significant reduction in the presence of cations such as $\mathrm{Na}^{+}, \mathrm{K}^{+}, \mathrm{Ca}^{2+}$, and $\mathrm{Mg}^{2+}$, due to the zeolite preference to adsorb ions. The order of selectivity in this system was defined as $\mathrm{Na}^{+}>\mathrm{K}^{+}>-$ $\mathrm{Ca}^{2+}>\mathrm{Mg}^{2+}>\mathrm{NH}_{4}{ }^{+}$. Lin et al. [91] evaluated the use of chabazite natural zeolite to remove ammonia from swine manure. The chabazite used in the tests had high calcium content, and according to the authors, the exchange rate between calcium and ammonia occurs more slowly than that for sodium, due to the higher resistance to the diffusion of $\mathrm{Ca}^{2+}$, something that contributes to the reduction of the adsorption rate. In a study conducted by Haji et al. [4], on the removal of $\mathrm{NH}_{4}{ }^{+}$ using zeolite $\mathrm{Y}$ with different compensation cations, $\mathrm{Na}^{+}$ proved to have the highest ammonia removal potential (91.8\%), followed by $\mathrm{Cs}^{+}$(24.8\%), $\mathrm{K}^{+}$(24.3\%), $\mathrm{Mg}^{2+}$ (18.5\%), and $\mathrm{Ca}^{2+}(18.5 \%)$. The authors also made a comparison with the performance of zeolite $\mathrm{X}$ in the removal of ammonia (both with $\mathrm{Na}^{+}$cation), which presented an $83.8 \%$ removal. The authors stated that, although zeolite $\mathrm{X}$ has a lower $\mathrm{Si} / \mathrm{Al}$ ratio (which consequently results in a higher CEC), zeolite $\mathrm{Y}$ has a greater surface area $\left(980 \mathrm{~m}^{2} \cdot \mathrm{g}^{-1}\right.$ vs. $\left.527 \mathrm{~m}^{2} \cdot \mathrm{g}^{-1}\right)$, which increases its performance as an adsorbent.

Table 5 summarizes several studies utilizing zeolites as adsorbents to remove ammonia. A direct comparison of the efficiency of different zeolite types in the removal of ammonia is difficult, due to the variability of the experimental conditions. Zeolite dosage, ammonia concentration, and contact time are factors that strongly influence adsorption, and as seen in Table 5, these variables were investigated over a wide range. Ideally, it would be necessary to develop standardized tests, under the same conditions, to identify the best zeolite to be used for ammonia removal. However, synthetic zeolites with larger pore openings showed the highest removal capacity, as in the case of zeolites $\mathrm{X}$ and $\mathrm{A}$.

3.1.3. Phosphoric Compounds. As zeolites have low efficiency in removing anionic species in solution, the removal of phosphoric compounds can be especially challenging, as they are present in solution in the anionic form, in a wide $\mathrm{pH}$ range. Below $\mathrm{pH} 2$, the predominant species is $\mathrm{H}_{3} \mathrm{PO}_{4}$, while at $\mathrm{pH}$ between 2 and 7 , between 7 and 12, and above 12 , the dominant species are $\mathrm{H}_{2} \mathrm{PO}_{4}{ }^{-}, \mathrm{HPO}_{4}{ }^{2-}$, and $\mathrm{PO}_{4}{ }^{3-}$, respectively, which result in electrostatic repulsion due to the negative charge. In the acidic $\mathrm{pH}$ range, however, sites on the zeolite surface undergo protonation, acquiring a positive electrical charge and attracting phosphate ions, which is followed by chemical interaction between the molecular species and the zeolite surface. This effect was verified by Zhang et al. [92], using granular natural zeolite to remove phosphorus from effluent. In removal tests in different $\mathrm{pH}$ ranges $(1.8-12)$, it was found that the highest removal rate (close to $100 \%$ ) occurred at $\mathrm{pH} 2$, reaching close to $0 \%$ at $\mathrm{pH} 7$ and increasing slightly in the alkaline $\mathrm{pH}$ range. The authors state that alkaline conditions lead to chemical precipitation, which might explain this behavior. In contrast, adsorption is favored by the expansion of the zeolite pores in acidic $\mathrm{pH}$, which contributes to the increase in the surface area available for adsorption. Hamdi and Srasra [93] compared the phosphate adsorption using clay minerals (kaolinite+illite and kaolinite+smectite) and zeolite $\mathrm{A}$. The $\mathrm{pH}$ at which the zeolite showed greater adsorption was 5.5, below the PZC of the zeolite A (PZC =6.7) [94]. The authors explained that the adsorption of phosphate anions in zeolite occurs at positive sites that are protonated at acidic $\mathrm{pH}$. The attraction of negatively charged molecules at these sites is followed by chemical interaction, leading to higher phosphate adsorption.

The modification of the surface of zeolites is a factor that contributes positively to the adsorption of phosphates since the chemical interaction between species and surfaces often exceeds the electrostatic repulsion between them. Goscianska et al. [95] evaluated the modification of synthetic zeolites $\mathrm{NaP} 1$ and $\mathrm{NaA}$ and natural clinoptilolite with lanthanum, aiming to investigate phosphate adsorption. After the modification, the specific surface area and pore volume were reduced in all varieties of zeolites. However, the amount of phosphate adsorbed by the modified zeolites was higher, especially in the case of synthetic zeolites. The authors attributed this increase in adsorption to the fact that lanthanum has a greater affinity to phosphate. X-ray diffraction tests revealed crystallized lanthanum phosphate peaks in the samples after the adsorption tests, which explains why the adsorption increased even with the reduction of the specific surface area and pore volume. Alshameri et al. [96] studied the potential of using clinoptilolite zeolite and its modified version with tetra butyl titanate to remove $\mathrm{PO}_{4}{ }^{3-}$. The authors state that, in this case, it is necessary to modify the surface of the zeolite using inorganic salts or organic surfactants that lead to the appearance of sites with a positive charge. As can be seen in Table 6, the adsorption capacity of natural and synthetic zeolites for phosphate is relatively low, when compared to the other contaminants evaluated in this study. However, the modification is a factor that contributes significantly to increasing the adsorption capacity.

Temperature also presents an important role in phosphate adsorption using zeolite. The increase in temperature positively affects the adsorption capacity. The phosphate molecules move more quickly in the solution, increasing their efficiency in the adsorption of the contaminant. Goscianska et al. [95] verified the increase of the adsorption capacity from 10.5 to $16.2 \mathrm{mg}^{-1}$ and 57.7 to $63.9 \mathrm{mg} \cdot \mathrm{g}^{-1}$, for the synthetic and modified zeolites $\mathrm{NaP} 1$ and $\mathrm{LaP} 1$, respectively, when the temperature was varied from 25 to $60^{\circ} \mathrm{C}$, demonstrating the endothermic character of the process.

In the adsorption of anionic species, such as phosphoric compounds, $\mathrm{pH}$ control is of fundamental importance. In the case of zeolites, $\mathrm{pH}$ below the point of zero charges (PZC) provides the appearance of positive sites at the adsorbent surface, which makes adsorption possible.

\subsection{Organic Compound Removal}

3.2.1. Dyes. The removal of dyes on zeolite surfaces occurs by ion exchange properties. Table 7 shows the results of several 
TABLe 6: Phosphate removal by different zeolites, along with experimental conditions and adsorption and kinetic models.

\begin{tabular}{|c|c|c|c|c|c|c|c|c|c|}
\hline Zeolite & $\begin{array}{c}T \\
\left({ }^{\circ} \mathrm{C}\right) \\
\end{array}$ & $\begin{array}{l}\text { Contact } \\
\text { time }\end{array}$ & $\begin{array}{c}\text { Concentration } \\
\left(\mathrm{mg} \cdot \mathrm{L}^{-1}\right)\end{array}$ & $\begin{array}{c}\mathrm{S} / \mathrm{L} \text { ratio } \\
\left(\mathrm{g} \cdot \mathrm{L}^{-1}\right)\end{array}$ & $\mathrm{pH}$ & $\begin{array}{l}\mathrm{PO}_{4}{ }^{3-} \text { sorption } \\
\text { capacity }\left(\mathrm{mg} \mathrm{g}^{-1}\right)\end{array}$ & $\begin{array}{c}\text { Adsorption } \\
\text { isotherm model }\end{array}$ & $\begin{array}{c}\text { Adsorption } \\
\text { kinetic model }\end{array}$ & References \\
\hline $\mathrm{NaP} 1$ & \multirow{6}{*}{$\begin{array}{c}25- \\
60\end{array}$} & \multirow{6}{*}{$24 \mathrm{~h}$} & \multirow{6}{*}{$12.5-200$} & \multirow{6}{*}{1} & \multirow{6}{*}{5.3} & 11.4 & \multirow{6}{*}{ Langmuir } & \multirow{6}{*}{-} & \multirow{6}{*}{ [95] } \\
\hline $\mathrm{LaP} 1$ & & & & & & 58.2 & & & \\
\hline $\mathrm{NaA}$ & & & & & & 15.7 & & & \\
\hline $\mathrm{LaA}$ & & & & & & 48.9 & & & \\
\hline Clinoptilolite & & & & & & 20.2 & & & \\
\hline La-clinoptilolite & & & & & & 25.5 & & & \\
\hline Fe-heulandite & 25 & $3 \mathrm{~h}$ & $1-16$ & 2.4 & 7 & $<0.2$ & Freundlich & - & [168] \\
\hline Granular zeolite & 25 & $20 \mathrm{~min}$ & 20 & 25 & 1.8 & 3.3 & Langmuir & - & [92] \\
\hline Zeolite A & 70 & $4 \mathrm{~h}$ & $50-1000$ & 6.6 & 5 & 52.9 & Langmuir & $\begin{array}{l}\text { Pseudo-second- } \\
\text { order }\end{array}$ & [93] \\
\hline Clinoptilolite & \multirow[b]{2}{*}{25} & \multirow[b]{2}{*}{$2 \mathrm{~h}$} & \multirow[b]{2}{*}{$10-100$} & 48 & & 1.3 & \multirow[b]{2}{*}{ Langmuir } & \multirow[b]{2}{*}{-} & \multirow[b]{2}{*}{ [96] } \\
\hline $\begin{array}{l}\mathrm{TiO}_{2} \text {-modified } \\
\text { clinoptilolite }\end{array}$ & & & & 20 & $\begin{array}{c}2- \\
4\end{array}$ & 34.2 & & & \\
\hline
\end{tabular}

studies using zeolites as adsorbents for dyes. As can be seen, synthetic zeolites have a greater adsorption capacity compared to natural ones, reflecting their greater degree of composition uniformity and physical properties (e.g., crystalline structure, pore size, and compensation cations).

Zeolites exhibit different ion adsorption selectivity and competitive adsorption in multicomponent systems. Ayar et al. [97] used natural clinoptilolite and zeolites synthesized from fly ash (analcime+sodalite) to evaluate the removal of safranine $\mathrm{O}(\mathrm{SO})$ dye in the presence of $\mathrm{Cs}^{+}$. The authors noticed that the increase in $\mathrm{Cs}^{+}$concentration leads to a reduction in the removal of $\mathrm{SO}$ for both zeolites since the $\mathrm{Cs}^{+}$ions compete with the SO molecules for the active sites on the surface of the zeolite samples. Due to the difference in the pore sizes of the zeolites used, the results also indicate greater adsorption of SO by clinoptilolite (4.1 $\AA$ ) in comparison with analcime and sodalite (3.2 and $2.3 \AA$, respectively).

In dye adsorption systems, it is important to consider the size of the molecule to be adsorbed, as this parameter strongly affects the adsorption efficiency. Wang and Zhu [98] carried out a comparative study on the removal of methylene blue and rhodamine B dyes by clinoptilolite zeolite. The larger size of the rhodamine B molecule was indicated to impair the diffusion process in the zeolite pores. The removal capacity verified for this compound, at room temperature, was $9.3 \mathrm{mg} \cdot \mathrm{g}^{-1}, 55 \%$ of the capacity verified for methylene blue $\left(16.7 \mathrm{mg} \cdot \mathrm{g}^{-1}\right)$. In addition to the adsorption capacity, the relationship between the size of pores and pigment molecules directly affects the adsorption rate. As seen in Table 7, for natural zeolites (e.g., clinoptilolite, analcime, sodalite, and erionite), the equilibrium time is considerably longer, compared to synthetic zeolites (e.g., X and $\mathrm{Y}$ ), which is explained by the considerably larger pores and greater adsorption capacity, even at shorter contact time [98].

The $\mathrm{pH}$ adjustment is also of great importance for the removal of dyes in zeolite adsorption systems. In $\mathrm{pH}$ in the basic range, the presence of $\mathrm{OH}^{-}$causes a deprotonation reaction in the zeolite, inducing an increase in the negative electric charge, which intensifies the adsorption of cationic species. As verified by Oukil et al. [99], the adsorption of methylene blue (MB), a cationic dye, reaches its maximum value at $\mathrm{pH}$ 8. Lower adsorption was verified at $\mathrm{pH} 3$, due to competition with $\mathrm{H}^{+}$ions, in addition to protonation reaction, which makes the zeolite surface charge positive, thus causing electrostatic repulsion between species. Badeenezhad et al. [100] found that the $\mathrm{pH}$ variation strongly affects the adsorption of clinoptilolite in its natural form, reaching maximum removal of $\mathrm{MB}$ in the $\mathrm{pH}$ range between 7 and 9. As for the clinoptilolite modified using iron oxide nanoparticles, the adsorption did not show much variation with the $\mathrm{pH}$ change, reaching removals greater than $96.4 \%$ in the $\mathrm{pH}$ range between 3 and 9. The authors state that an alkaline $\mathrm{pH}$, the association of a small amount of available $\mathrm{H}^{+}$, and the negative surface charge increase the electrostatic attraction of the MB molecules, favoring adsorption. In the case of modified clinoptilolite, the $\mathrm{OH}^{-}$groups form hydroxy complexes with iron oxide present in the zeolite structure, which contributes to reducing the amount of MB adsorbed. Mittal et al. [101] used zeolite Y to remove brilliant green (BG) dye from the solution. The removal was analyzed in solutions with $\mathrm{pH}$ ranging from 2 to 11 . In the case of removal of BG by zeolite $\mathrm{Y}, 78 \%$ of dye was removed when the $\mathrm{pH}$ of the solution had been adjusted to 6 , with no gains in removal being observed at higher $\mathrm{pH}$ values, whereas a reduction in the amount of dye removed was observed below $\mathrm{pH}$ 6. Cationic dyes are best removed by the zeolite at $\mathrm{pH}$ above the point of zero charges (PZC), in which the zeolite surface presents a negative charge. Previous studies indicate that most zeolites present $\mathrm{PZC}$ at $\mathrm{pH}$ close to neutrality, as verified for zeolites $\mathrm{A} \quad(\mathrm{PZC}=6.7) \quad[102], \mathrm{Y} \quad(\mathrm{PZC}=5.8)$ [94], NaP1 $(\mathrm{PZC}=6.5)$ [94], sodalite $(\mathrm{PZC}=6.5) \quad$ [103], and clinoptilolite $(\mathrm{PZC}=8)$ [103]. As natural and synthetic zeolites have shown much lower adsorption of anionic dyes compared to cationic ones, due to electrostatic repulsion, $\mathrm{pH}$ adjustment becomes of fundamental importance in the removal of these species since zeolites can acquire positive charge in $\mathrm{pH}<\mathrm{PZC}$. As verified by Garg et al. [104] when 


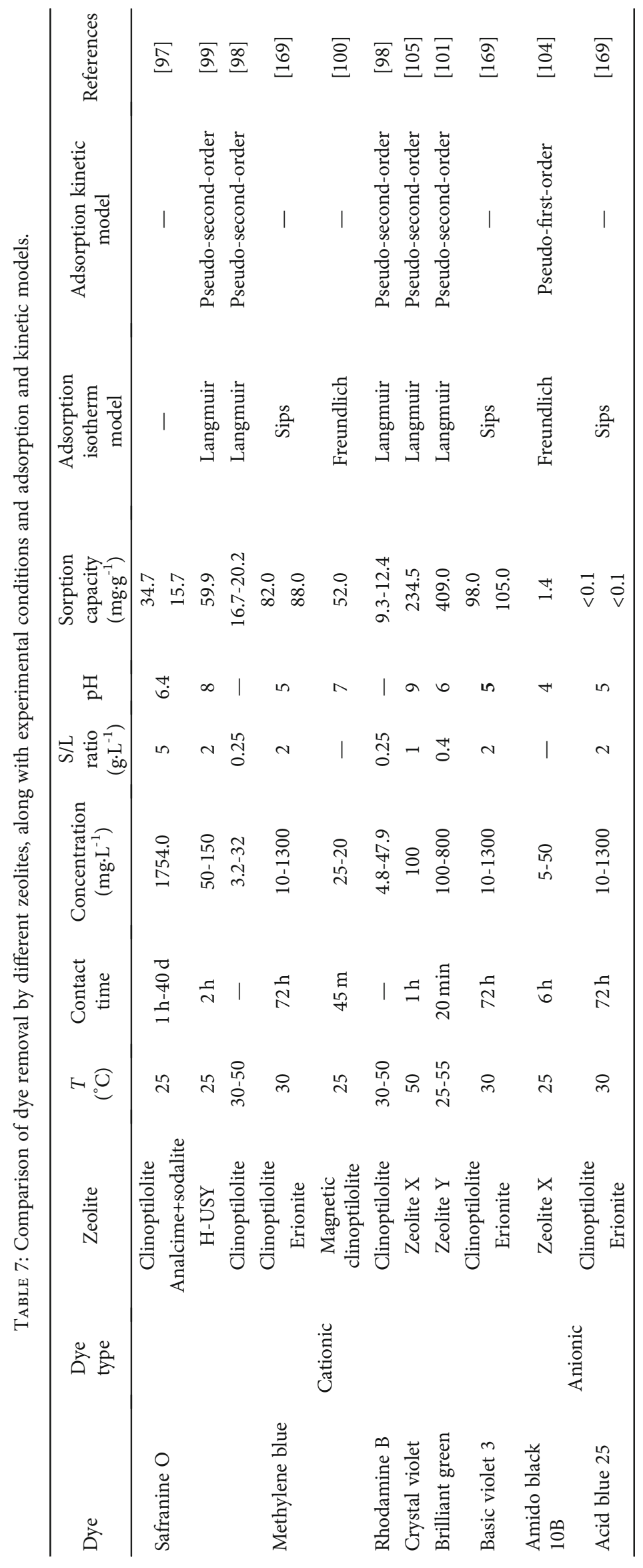


TABLE 8: Zeolites used in organic compound removal, along with experimental conditions and adsorption and kinetic models.

\begin{tabular}{|c|c|c|c|c|c|c|c|c|c|c|}
\hline $\begin{array}{l}\text { Organic } \\
\text { compound }\end{array}$ & Zeolite & $\begin{array}{c}T \\
\left({ }^{\circ} \mathrm{C}\right)\end{array}$ & $\begin{array}{l}\text { Contact } \\
\text { time }\end{array}$ & Concentration & $\begin{array}{c}\mathrm{S} / \mathrm{L} \\
\text { ratio } \\
\left(\mathrm{g} \cdot \mathrm{L}^{-1}\right)\end{array}$ & $\mathrm{pH}$ & $\begin{array}{l}\text { Sorption } \\
\text { capacity } \\
\left(\mathrm{mg} \cdot \mathrm{g}^{-1}\right)\end{array}$ & $\begin{array}{l}\text { Adsorption } \\
\text { isotherm }\end{array}$ & $\begin{array}{l}\text { Adsorption } \\
\text { kinetics }\end{array}$ & References \\
\hline $\begin{array}{l}\text { Toluene } \\
\text { Styrene } \\
\text { Indene } \\
\text { Hexadecane } \\
\text { Octadecane } \\
\text { Dioctyl } \\
\text { phthalate }\end{array}$ & $\begin{array}{l}\text { CTAB- } \\
\text { zeolite Y }\end{array}$ & - & $8 \mathrm{~h}$ & $43 \mathrm{ppm}$ & 1 & - & 30.9 & Langmuir & - & [109] \\
\hline Triclosan & $\begin{array}{l}\text { FAU-type } \\
\text { BEA-type } \\
\text { MOR-type }\end{array}$ & 25 & $24 \mathrm{~h}$ & $0.3-17.4$ & 30 & - & $\begin{array}{l}377.6 \\
119.0 \\
153.2\end{array}$ & Langmuir & - & [107] \\
\hline \multirow{5}{*}{ Phenol } & $\begin{array}{l}\text { HDTMA- } \\
\text { clinoptilolite } \\
\text { BDTDA- } \\
\text { clinoptilolite }\end{array}$ & 20 & $4 \mathrm{~h}$ & $10-50 \mathrm{ppm}$ & $20-100$ & - & $\begin{array}{l}0.8 \\
1.3\end{array}$ & Freundlich & - & {$[110]$} \\
\hline & $\begin{array}{l}\text { HDTMA- } \\
\text { ZSM-5 }\end{array}$ & & & & & & 6.2 & & & \\
\hline & $\begin{array}{l}\text { CPB-ZSM-5 } \\
\text { HDTMA- } \\
\text { clinoptilolite }\end{array}$ & - & $24 \mathrm{~h}$ & $\begin{array}{c}0.0816- \\
1.2 \mathrm{mmol} / \mathrm{L}\end{array}$ & 5 & - & 11.4 & $\begin{array}{c}\text { Langmuir/ } \\
\text { Freundlich/ } \\
\text { Redlich-Peterson }\end{array}$ & - & [112] \\
\hline & $\begin{array}{c}\text { CPB- } \\
\text { clinoptilolite }\end{array}$ & & & & & & 11.9 & & & \\
\hline & MCM-41 & & & & & & 59.4 & & & \\
\hline \multirow{2}{*}{ 4-Chlorophenol } & $\begin{array}{l}\text { HDTMA- } \\
\text { clinoptilolite }\end{array}$ & 20 & $4 \mathrm{~h}$ & $10-100 \mathrm{ppm}$ & $20-100$ & - & 12.7 & \multirow{2}{*}{ Freundlich } & \multirow{2}{*}{ - } & \multirow{2}{*}[110]{} \\
\hline & $\begin{array}{l}\text { BDTDA- } \\
\text { clinoptilolite }\end{array}$ & 20 & $4 \mathrm{~h}$ & $10-100 \mathrm{ppm}$ & $20-100$ & - & 6.41 & & & \\
\hline $\begin{array}{l}2,4,6- \\
\text { Trichlorophenol }\end{array}$ & FAU-type & 25 & $24 \mathrm{~h}$ & $1-60 \mu \mathrm{mol} / \mathrm{L}$ & 30 & - & 314.5 & Langmuir & & [107] \\
\hline \multirow{4}{*}{ Toluene } & HDTMA-Y & 28 & $6 \mathrm{~h}$ & $1-60 \mathrm{mg} / \mathrm{L}$ & 30 & - & 152.4 & Temkin & $\begin{array}{l}\text { Pseudo- } \\
\text { second- } \\
\text { order }\end{array}$ & [111] \\
\hline & $\begin{array}{l}\text { HDTMA- } \\
\text { ZSM-5 }\end{array}$ & - & $24 \mathrm{~h}$ & $\begin{array}{c}0.0816- \\
1.2 \mathrm{mmol} / \mathrm{L}\end{array}$ & 5 & - & 9.3 & \multirow{3}{*}{$\begin{array}{c}\text { Langmuir/ } \\
\text { Freundlich/ } \\
\text { Redlich-Peterson }\end{array}$} & \multirow{3}{*}{-} & \multirow{3}{*}[112]{} \\
\hline & CPB-ZSM-5 & - & $24 \mathrm{~h}$ & $\begin{array}{c}0.0816- \\
1.2 \mathrm{mmol} / \mathrm{L}\end{array}$ & 5 & - & 16.4 & & & \\
\hline & MCM-41 & - & $24 \mathrm{~h}$ & $\begin{array}{c}0.0816- \\
1.2 \mathrm{mmol} / \mathrm{L}\end{array}$ & 5 & - & 145.2 & & & \\
\hline \multirow{5}{*}{ Benzene } & HDTMA-Y & 28 & $6 \mathrm{~h}$ & $1-60 \mathrm{mg} / \mathrm{L}$ & 30 & - & 150.4 & Temkin & $\begin{array}{l}\text { Pseudo- } \\
\text { second- } \\
\text { order }\end{array}$ & [111] \\
\hline & $\begin{array}{l}\text { HDTMA- } \\
\text { ZSM-5 }\end{array}$ & & & & & & 7.7 & \multirow{4}{*}{$\begin{array}{c}\text { Langmuir/ } \\
\text { Freundlich/ } \\
\text { Redlich-Peterson }\end{array}$} & \multirow{4}{*}{-} & \multirow{4}{*}[112]{} \\
\hline & CPB-ZSM-5 & & & & & & 15.0 & & & \\
\hline & $\begin{array}{l}\text { HDTMA- } \\
\text { clinoptilolite } \\
\text { CPB- } \\
\text { clinoptilolite }\end{array}$ & - & $24 \mathrm{~h}$ & $\begin{array}{c}0.0816- \\
1.2 \mathrm{mmol} / \mathrm{L}\end{array}$ & 5 & - & 16.6 & & & \\
\hline & MCM-41 & & & & & & 112.3 & & & \\
\hline Ethylbenzene & HDTMA-Y & \multirow{3}{*}{28} & \multirow{3}{*}{$6 \mathrm{~h}$} & \multirow{3}{*}{$1-60 \mathrm{mg} / \mathrm{L}$} & \multirow{3}{*}{30} & \multirow{3}{*}{-} & 162.2 & \multirow{3}{*}{\multicolumn{2}{|c|}{$\begin{array}{l}\text { Pseudo- } \\
\text { second- } \\
\text { order }\end{array}$}} & \multirow{3}{*}[111]{} \\
\hline m,p-Xylene & HDTMA-Y & & & & & & 175.3 & & & \\
\hline o-Xylene & HDTMA-Y & & & & & & 164.6 & & & \\
\hline
\end{tabular}


studying the adsorption of amido black 10B, an anionic dye, the highest removal rate occurred in the $\mathrm{pH}$ range between 2 and 5. Above this $\mathrm{pH}$ value, the studied zeolite (synthetic zeolite $\mathrm{X}$ ) acquires a negative electrical charge, which leads to electrostatic repulsion and consequent reduction in the removal of the contaminant.

Temperature also plays an important role in dye adsorption using zeolites. The temperature increases the mobility of the ions and promotes the expansion of the crystalline structure of the zeolite, which causes an increase in the adsorption rate [105]. Wang and Zhu [98] analyzed the adsorption of $\mathrm{MB}$ and rhodamine $\mathrm{B}$ in natural clinoptilolite. The increase in temperature positively affected the adsorption, and for both dyes, the amount adsorbed was greater at approximately $50^{\circ} \mathrm{C}$, showing the endothermic characteristic of the adsorption. On the other hand, the increase in temperature may lead to a reduction in the removal of contaminants, as verified by Garg et al. [104], who noted that raising the temperature from $293 \mathrm{~K}$ to $333 \mathrm{~K}$ resulted in a reduction in the removal of amido black $10 \mathrm{~B}$ from $73.4 \%$ to $48.6 \%$, due to desorption of dye molecules. Temperature becomes a factor that deserves attention, since different zeolite-dye systems can possess endothermic or exothermic behavior, leading to a positive or negative influence on the removal process. As seen in Table 7, temperature is a parameter that was not investigated in most of the studies analyzed in this review, and, as mentioned, it can affect adsorption in different ways. Further in-depth studies on the influence of temperature on dye adsorption using zeolites can provide insightful information.

3.2.2. Organic Species. The adsorption of organic compounds using zeolites is significantly dependent on the adsorbent Si/Al ratio. Low-silica zeolites present a greater amount of aluminum content in their composition, resulting in more compensation cations available, which increases their effectiveness in cation exchange. In contrast, highsilica zeolites present greater hydrophobicity and organic compound removal [106-108]. The adsorption capacity of organics on low-silica zeolites, as well as the affinity for anions, can be amplified with modifications using surfactants. This can be seen in Table 8, which shows studies on the removal of several organic compounds using surfactantmodified zeolites as adsorbents. The modification occurs due to the formation of a surfactant monolayer on the zeolite surface, with the hydrocarbon chain of the molecule facing the solution and making the zeolite hydrophobic. The surfactant concentration is of great importance because if the critical micellar concentration (CMC) is exceeded, a surfactant double layer should be formed, which returns the hydrophilic character to the zeolite [58]. Hosseini Hashemi et al. [109] evaluated the use of zeolite $\mathrm{Y}$, modified with hexadecyltrimethylammonium bromide (CTAB), to remove organic pollutants from an olefin plant. Zeolite Y was modified with different concentrations of $\mathrm{CTAB}$, to evaluate the influence of surfactant concentration on the removal of organic compounds. The best results were obtained with $0.025 \mathrm{M} \mathrm{CTAB}$, whereas higher concentrations led to the formation of a double layer, increasing the hydrophilicity of the zeolitic particles and reducing the adsorption of the organic compounds. The adsorption of organic compounds in CTAB-modified zeolite $\mathrm{Y}$ follows the Langmuir model, whose adsorption occurs in monolayer and all sites have the same affinity for adsorbate. As all the analyzed isotherm models (Freundlich, Sips, and Dubinin-Radushkevich) presented acceptable errors, it can also be concluded that the adsorption is favorable and that it occurs basically by physical mechanisms (physisorption) [109].

Jiang et al. [107] investigated the adsorption of three organic compounds (triclosan, phenol, and 2,4,6-trichlorophenol) using four synthetic high-silica zeolites, belonging to the FAU, BEA, MFI, and MOR structures. For triclosan adsorption, FAU-type zeolite showed the highest adsorption capacity, followed by MOR and BEA-type. MFI-type zeolite was demonstrated to have a very low adsorption capacity for triclosan. In the case of trichlorophenol, the adsorption sequence was maintained, again with emphasis on the greater adsorption in the zeolite of the FAU structure. As for phenol, the amount adsorbed by all types of zeolites was lower than that for the other compounds. However, the MFI-type zeolite stood out in the removal of this chemical compound, followed by the MOR, BEA, and FAU zeolites. The authors associated the adsorption of organic compounds with the size of their hydrocarbon chains and the pore size of zeolites. In the case of FAU-type zeolite, the adsorption of trichlorophenol was greater than triclosan due to the smaller size of the first species; therefore, more molecules could pass through the pores of the FAU zeolite. The adsorption of phenol was shown to be greater in the MFI zeolite, which is the zeolite with the smallest pore size. The authors state that pores with the same order of magnitude as the molecules of organic compounds favor adsorption due to the generation of a greater attraction force between the compound and active sites in the micropores. The organic compound triclosan has been shown to adsorb following the Langmuir model, regardless of the zeolite used. Trichlorophenol followed the Langmuir model only for the FAU zeolite and adsorbed forming multilayers in the other zeolites, following the Freundlich model. Phenol was adsorbed following the Freundlich model in all the zeolites studied. According to the authors, the hydrophobicity of zeolites has secondary importance. The type and size of organic molecules (which may lead to intermolecular attraction between molecules on the adsorbent), pore size, and crystalline structure of zeolites were more relevant features in the process.

Kuleyin [110] analyzed the removal of phenol and 4chlorophenol using natural clinoptilolite, modified with hexadecyltrimethyl ammonium (HDTMA). The authors observed that 4-chlorophenol showed the highest adsorption rate in modified clinoptilolite, since the reagent is more hydrophobic than phenol, showing a greater affinity for zeolites covered by surfactants. In terms of comparison, in the experimental conditions of $20 \mathrm{~g} \cdot \mathrm{L}^{-1}$ of adsorbent, $20^{\circ} \mathrm{C}$, and initial concentration of $50 \mathrm{mg} \cdot \mathrm{L}^{-1}$, natural clinoptilolite showed removal $<10 \%$ for chlorophenol and $<5 \%$ for phenol, whereas modified clinoptilolite showed removals of approximately $60 \%$ for phenol and $90 \%$ for chlorophenol. 
TABLE 9: Most used models to describe the adsorption isotherm and kinetics of zeolites in wastewater treatment systems.

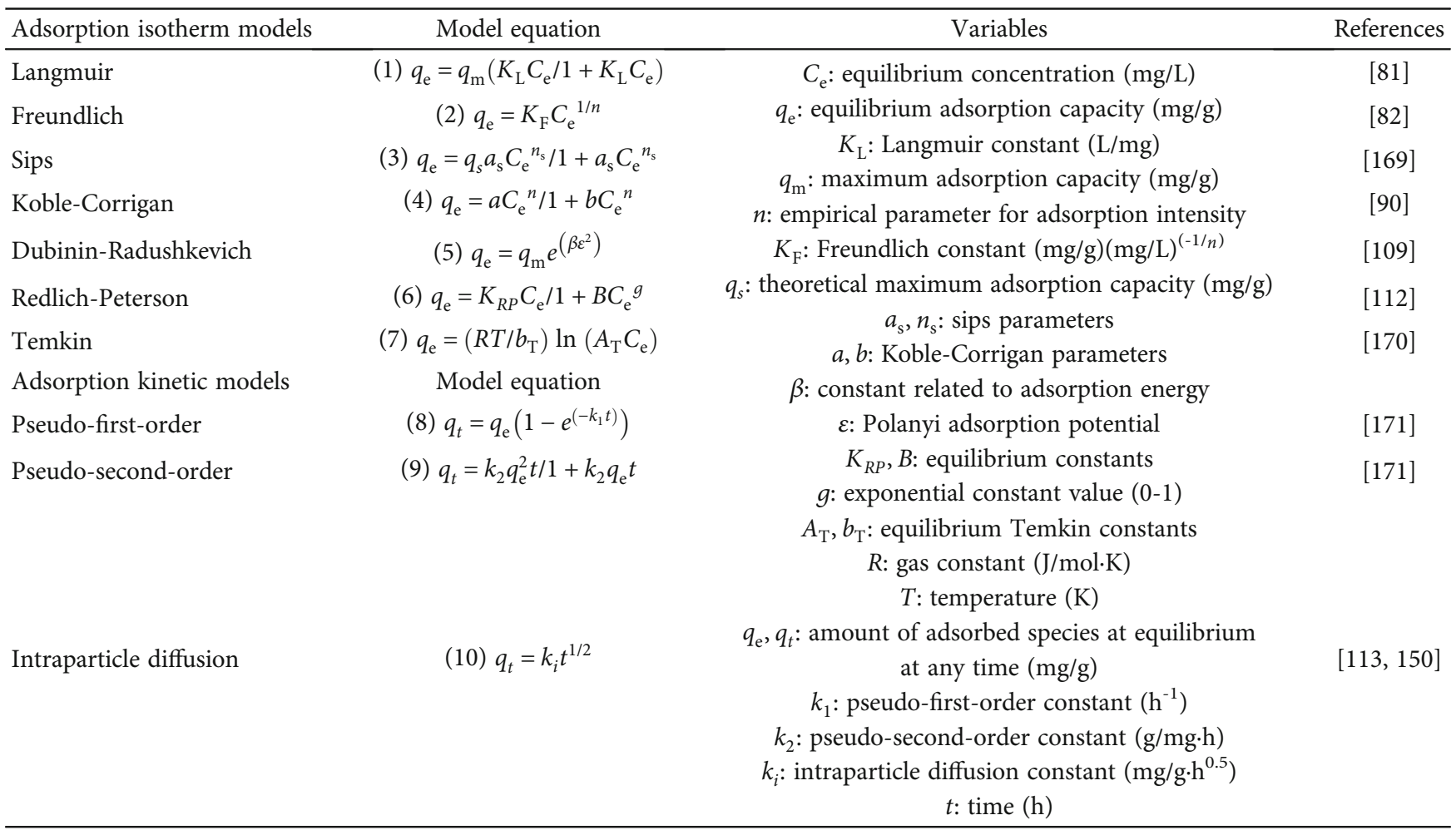

Vidal et al. [111] performed the removal of benzene, ethylbenzene, toluene, o-xylene, and m,p-xylene Y-modified zeolite with HDTMA. The zeolites were modified in different concentrations of HDTMA, using 50, 100, and 200\% of the cation exchange capacity (CEC) of the zeolite Y. It was found that the concentration of HDTMA that results in the greatest removal of the analyzed organic compounds was $100 \%$ of the CEC. Concentrations of 50 and $200 \%$ lead to an incomplete coating of the zeolite surface and the formation of a double layer of surfactant, respectively, which impairs the adsorption of the compounds. The maximum adsorption capacities obtained by the Langmuir model were 150.42, 152.41, 162.22, 175.32 , and $164.58 \mathrm{mg} \cdot \mathrm{g}^{-1}$ for benzene, toluene, ethylbenzene, m,p-xylene, and o-xylene, respectively. Ghiaci et al. [112] used natural clinoptilolite, ZSM-5, and MCM-41 to remove toluene, benzene, and phenol. The zeolites (except MCM41) were modified with HDTMA bromide and $n$-cetyl pyridinium bromide $(\mathrm{CPB})$, in different concentrations $(0.5,1.8$, and $\left.20 \mathrm{mmol} \cdot \mathrm{L}^{-1}\right)$. The authors state that the pores of all the zeolites investigated are smaller than the surfactants used in the modification, which would be adsorbed only on the external surface of the particles. It was found that, in all cases, the adsorption of organic compounds on zeolites modified with $\mathrm{CPB}$ was greater than in those modified with HDTMA. The authors explained that this is due to the more hydrophobic nature of CPB compared to HDTMA, increasing the interaction of $\mathrm{CPB}$ with the organic compounds analyzed. The study revealed the greater adsorption capacity of benzene, toluene, and phenol in zeolite MCM-41, which even without previous treatment showed adsorption capacities five times greater than those of clinoptilolite and ZSM-5.
3.3. Kinetic Studies. The adsorption kinetic models help to understand the mass transfer adsorption mechanisms, in addition to providing information about the adsorption rate and general performance of the adsorbent [80]. Ideally, an ideal adsorbent should possess a high adsorption capacity allied with a rapid adsorption rate. The mass transfer mechanism includes three steps. The first is the external diffusion, in which the adsorbate is transferred to the solid through a liquid film layer. The concentration of adsorbate governs the driving force, and the external diffusion occurs faster in the case of higher concentrations. The second step is the internal diffusion when the adsorbate penetrates the pores. Finally, the third step is the interaction of the adsorbate with the active sites in the adsorbent [113]. Table 9 shows the equations of the most widely used adsorption isotherm and adsorption kinetic models applicable for adsorption systems, including zeolites as adsorbents. The pseudo-second-order model best fits the experimental data in the studies analyzed in this review (as verified in Tables 3-8). This model, adequate for solutions with low concentration, indicates that the material utilized as adsorbent possesses a large number of active sites. Low silica zeolites possess a high amount of aluminum in their crystallographic structure, each one representing an active point for adsorption, which is why the second-order model is the one that best represents the phenomenon. Despite being widely applied in adsorption kinetic studies, pseudo-first- and pseudo-second-order models cannot explain the mass transfer mechanism, being considered empirical models. Thus, the mechanism is better explained by internal diffusion models such as the intraparticle diffusion model. This model assumes that the diffusion of 
adsorbate into the pores of the adsorbent is the slowest step in the adsorption process. Graphically, the process is represented by a straight line that may pass through the origin. In this case, intraparticle diffusion is the only mechanism that limits the process, and the adsorption on the outer layer takes place instantaneously. Otherwise, there is an indication that more than one mechanism is controlling the adsorption process [113].

In the case of heavy metal adsorption, the intraparticle diffusion model has also shown adherence in some studies, as verified by Jin et al. [114], indicating that the adsorption occurs initially on the external surface of the particles, followed by adsorption within the pores in the crystalline structure of the particles. Since metallic ions present dimensions of the same order of magnitude of the pores, the adsorption occurs quickly, regardless of the zeolite used or the heavy metal to be removed.

For ammonia, results of adsorption experiments performed by Zhao et al. [90] and Lin et al. [91] indicated that in the first 5 minutes of contact, ammonia removal reached $56.4 \%$ for analcime and P zeolites and 50\% for chabazite zeolite, respectively. Although the intraparticle diffusion model did not present a good correlation with the experimental data, it is believed that the diffusion was the main adsorption mechanism acting in the first 30 minutes of contact [91].

Considering the adsorption of dyes, the data demonstrate that, for the zeolites and dyes analyzed, adsorption on the external surface occurs quickly. However, the intraparticle diffusion rate is quite reduced, reflecting the difficulty that the molecules present in entering the pores of the zeolite, due to its size. At this point, the more uniform chemical composition (greater stability of the $\mathrm{Si} / \mathrm{Al}$ ratio) and pore size of synthetic zeolites show greater adsorption potential for dyes. Once again, it is important to consider the relationship between the size of the dye molecule and the pore dimensions of the zeolite to assess the time required for the adsorption to occur, this information being essential to design the processes for removing this type of contaminant.

As for kinetics of phosphoric compound adsorption, Hamdi and Srasra [93] verified that most of the phosphorus was removed within a $2 \mathrm{~h}$ interval, with no further removals being verified after this time. This suggests that adsorption occurs only on the surface, and the entry of molecules into the interior of the zeolite pores was impaired. However, adsorption kinetics has not been investigated in most studies. Further studies on the kinetics of phosphoric compound removal using zeolites are necessary to have a better understanding of the adsorption process, in addition to allowing the determination of the optimal contact time for the design of treatment systems for this type of effluent.

The adsorption of organic compounds onto zeolites differs from the process of removal of other contaminants because hydrophobic interactions between adsorbent/adsorbate are of greater importance. The modification of zeolites using surfactants makes this interaction possible by the appearance of a hydrophobic monolayer at the zeolite surface. However, the surfactant molecules are too compared to the pore sizes, and the coating only occurs on the surface of the particles. Studies carried out by Kuleyin [110] demonstrate that removal occurs within the first 30 minutes of contact and quickly stabilizes, indicating that the diffusion in the zeolite pores is a limiting factor for adsorption. The process did not fit well with the intraparticle diffusion model, which confirms the external character of the adsorption of organic molecules. Since adsorption occurs on the surface of the particles, it is expected that the particle size of the zeolite used may influence the efficiency of the process. Considering natural zeolites, the comminution process can be optimized with prior knowledge of this parameter. However, granulometry is not among the physical parameters of the adsorbents used in the analyzed studies. Another factor that may influence the adsorption process, which has not been investigated, is $\mathrm{pH}$. The variation of this variable can affect the ionization state of the molecules, both the surfactant and the adsorbate, which can strongly influence the process.

3.4. Adsorption Isotherms. The analysis of adsorption isotherms reveals important information, such as maximum adsorption capacity $(\mathrm{mg} / \mathrm{g})$ and the adsorption mechanism, which can be used in the development of adsorption systems for wastewater treatment [76]. The isotherm models are represented by curves that relate the amount of adsorbate at the adsorbent surface and the concentration of the adsorbate in the liquid phase, at a constant temperature. Table 9 shows the existing adsorption isotherm models in the literature used to characterize the adsorption on microporous materials. The models most commonly adopted to represent the adsorption isotherms are the Langmuir and Freundlich models, which assume a uniform distribution in monolayers at the adsorbent surface and the multilayer adsorption on a heterogeneous surface of the adsorbent, respectively [76]. Temkin's model assumes the existence of an adsorbateadsorbate interaction, which confirms that the presence of hydrophobic tail group interaction is a dominant factor in the process. The Redlich-Peterson model is similar to the Langmuir and Freundlich models, but it is more suitable for wider ranges of contaminant concentration, also fitting well in processes with this characteristic [111].

According to data collected in Table 3, the Langmuir model was the one that best fitted the experimental data of the studies analyzed, indicating that the adsorption to the heavy metal system using zeolites as adsorbents occurs with the formation of a monolayer on the surface of the particles. The adsorption rate is higher in the first minutes of contact, at which more active sites are available for adsorption. As the sites on the surface are occupied, the ions migrate into the pores within the crystalline structure [114]. In addition to adsorption, ion exchange is also present as a mechanism for removing heavy metals in solution, as indicated by Bai et al. [115] and Hui et al. [82], who verified an increase in sodium concentration in solution after the equilibrium time is reached.

For ammonia adsorption, among the studies analyzed in Table 5, the Langmuir isotherm model showed the best adherence to experimental data, indicating that the adsorption of these molecules occurs with the formation of a 
monolayer. The Freundlich model also showed good applicability, indicating the heterogeneity of the adsorbent surface, in addition to the fact that the process occurs spontaneously [87].

Comparable to nitrogenous compounds and heavy metals, the dye adsorption process occurs mainly by cationic exchange and electrostatic interactions. The process is favored for zeolites with a lower $\mathrm{Si} / \mathrm{Al}$ ratio, in which the largest amount of aluminum atoms contributes to a greater negative charge. As each negative site is capable of adsorbing only one dye molecule, a monolayer is formed. As shown in Table 7, most studies indicate that the Langmuir isotherm best represents the adsorption process, which confirms this theory.

For phosphoric compounds, the process occurs by electrostatic attraction, and, as in the previous cases, each site can adsorb only one molecule, leading to the formation of a monolayer. The Langmuir isotherm illustrates this phenomenon well, and this model best fitted the experimental data available for the investigation on the use of zeolites as adsorbents.

In the case of organic compounds, the Langmuir model fits well with the experimental data, indicating that the hydrophobic interaction process allows the formation of a monolayer of contaminant molecules over the surfactant layer, and the process occurs spontaneously, as indicated by the good fitting of the Freundlich isotherm. As seen in Table 8 , there is also an indication of good adjustment by the Temkin and Redlich-Peterson isotherms, demonstrating the hydrophobic interaction between the adsorbate and the surfactant-modified zeolite.

\section{Conclusions, Challenges, and Future Perspectives}

Based on investigations conducted by several authors, it can be seen that synthetic zeolites have greater adsorption capacity for the various compounds analyzed, due to high degree ordering in the crystalline structure and, consequently, standardization of pore sizes and cation exchange capacity. Natural zeolites are less efficient since the presence of contaminating minerals reduces adsorption efficiency. Therefore, modification of natural zeolites is an alternative to enhancing their properties for application in wastewater treatment.

As for contaminants, heavy metals, dyes, and ammonium are readily adsorbed by zeolites, with fast kinetic rates. However, for anionic species, such as phosphoric compounds and some heavy metals (e.g., chromium and arsenic), adsorption is impaired, due to electrostatic repulsion, but possible at specific $\mathrm{pH}$ ranges. Organic compounds, which are predominantly hydrophobic, have been removed using zeolites by modifying them with surfactants, creating a hydrophobic layer on the surface of the zeolite, which increases its affinity for these compounds. In this case, the dosage of the surfactant becomes an important variable to be considered.

Despite a large number of bench-scale researches which show the effectiveness of zeolites as contaminant adsorbents, further studies on adsorption kinetics (phosphoric compounds), temperature (dyes), granulometry, and $\mathrm{pH}$ (organic compounds), desorption, and pilot-scale investigations are necessary. Furthermore, synthetic solutions are used in the research, which does not reflect the characteristics of real wastewater. The presence of other chemical species in this scenario could affect the adsorption mechanisms in different ways and is important to consider the presence of these elements to apply zeolite in large-scale industrial applications.

\section{Conflicts of Interest}

The authors declare that they have no conflicts of interest.

\section{Authors' Contributions}

Luciano Fernandes de Magalhães worked on conceptualization, investigation, data curation, writing (original draft), writing (review and editing), and visualization. Gilberto Rodrigues da Silva worked on writing (review and editing), supervision, and project administration. Antônio Eduardo Clark Peres worked on supervision.

\section{Acknowledgments}

The authors acknowledge $\mathrm{CNPq}$, Fundação de Amparo à Pesquisa do Estado de Minas Gerais, CAPES Foundation, and PROEX CAPES for the support to PPGEM. This study was financed in part by Coordenação de Aperfeiçoamento de Pessoal de Nível Superior-Brasil (CAPES)-Finance Code 001.

\section{References}

[1] T. Thorsteinsson, T. Jóhannesson, and Á. Snorrason, "Glaciers and ice caps: vulnerable water resources in a warming climate," Current Opinion in Environmental Sustainability, vol. 5, pp. 590-598, 2013.

[2] J. J. Bogardi, D. Dudgeon, R. Lawford et al., "Water security for a planet under pressure: interconnected challenges of a changing world call for sustainable solutions," Current Opinion in Environmental Sustainability, vol. 4, no. 1, pp. 35-43, 2012.

[3] M. Jaishankar, T. Tseten, N. Anbalagan, B. B. Mathew, and K. N. Beeregowda, "Toxicity, mechanism, and health effects of some heavy metals," Interdisciplinary Toxicology, vol. 7, pp. 60-72, 2014.

[4] S. Haji, B. A. Al-Buqaishi, A. A. Bucheeri, Q. Bu-Ali, M. AlAseeri, and S. Ahmed, "The dynamics and equilibrium of ammonium removal from aqueous solution by $\mathrm{Na}-\mathrm{Y}$ zeolite," Desalination and Water Treatment, vol. 57, article 189229001, 2016.

[5] H. Bacelo, A. M. A. Pintor, S. C. R. Santos, R. A. R. Boaventura, and C. M. S. Botelho, "Performance and prospects of different adsorbents for phosphorus uptake and recovery from water," Chemical Engineering Journal, vol. 381, 2020.

[6] M. M. Hassan and C. M. Carr, "A critical review on recent advancements of the removal of reactive dyes from dyehouse effluent by ion-exchange adsorbents," Chemosphere, vol. 209, pp. 201-219, 2018. 
[7] M. Trojanowicz, "Removal of persistent organic pollutants (POPs) from waters and wastewaters by the use of ionizing radiation," Sci Total Environ, vol. 718, article 134425, p. 134425, 2020.

[8] W. Zhao, Y. Liang, Y. Wu, D. Wang, and B. Zhang, "Removal of phenol and phosphoric acid from wastewater by microfiltration carbon membranes," Chemical Engineering Communications, vol. 205, pp. 1432-1441, 2018.

[9] M. N. Wu, X. C. Wang, and X. Y. Ma, "Phytotoxicity comparison of organic contaminants and heavy metals usingChlorella vulgaris," Desalination and Water Treatment, pp. 1-8, 2015.

[10] C. Kroeze, N. Hofstra, W. Ivens, A. Löhr, M. Strokal, and J. van Wijnen, "The links between global carbon, water, and nutrient cycles in an urbanizing world - the case of coastal eutrophication," Current Opinion in Environmental Sustainability, vol. 5, pp. 566-572, 2013.

[11] T. Wei, L. Guizhen, W. Tianli et al., "Preparation and adsorption of phosphorus by new heteropolyacid salt-lanthanum oxide composites," Desalination and Water Treatment, vol. 57, pp. 7874-7880, 2015.

[12] A. I. Zouboulis and L. Goetz, "Ion flotation as a tool for speciation studies selective separation in the system $\mathrm{Cr}^{3+} / \mathrm{Cr}^{6+}$," Toxicological \& Environmental Chemistry, vol. 31, pp. 539547, 1991.

[13] N. Muisa, I. Nhapi, W. Ruziwa, and M. M. Manyuchi, "Utilization of alum sludge as adsorbent for phosphorus removal in municipal wastewater: a review," Journal of Water Process Engineering, vol. 35, p. 101187, 2020.

[14] D. Shahidi, R. Roy, and A. Azzouz, "Advances in catalytic oxidation of organic pollutants - Prospects for thorough mineralization by natural clay catalysts," Applied Catalysis B: Environmental, vol. 174-175, pp. 277-292, 2015.

[15] Y. Wang, T. Du, H. Jia, Z. Qiu, and Y. Song, "Synthesis, characterization and $\mathrm{CO}_{2}$ adsorption of $\mathrm{NaA}, \mathrm{NaX}$, and NaZSM-5 from rice husk ash," Solid State Sciences, vol. 86, pp. 24-33, 2018.

[16] B. Schlichter, V. Mavrov, T. Erwe, and H. Chmiel, "Regeneration of bonding agents loaded with heavy metals by electrodialysis with bipolar membranes," Journal of Membrane Science, vol. 232, pp. 99-105, 2004.

[17] A. Dabrowski, Z. Hubicki, P. Podkoscielny, and E. Robens, "Selective removal of the heavy metal ions from waters and industrial wastewaters by ion-exchange method," Chemosphere, vol. 56, pp. 91-106, 2004.

[18] M. M. Marchioretto, H. Bruning, and W. Rulkens, "Heavy metals precipitation in sewage sludge," Separation Science and Technology, vol. 40, pp. 3393-3405, 2005.

[19] R. Chakraborty, A. Asthana, A. K. Singh, B. Jain, and A. B. H. Susan, "Adsorption of heavy metal ions by various low-cost adsorbents: a review," International Journal of Environmental Analytical Chemistry, pp. 1-38, 2022.

[20] M. Arif, G. Liu, B. Yousaf et al., "Synthesis, characteristics and mechanistic insight into the clays and clay minerals-biochar surface interactions for contaminants removal-a review," Journal of Cleaner Production, vol. 310, 2021.

[21] C. V. Lazaratou, D. V. Vayenas, and D. Papoulis, "The role of clays, clay minerals and clay-based materials for nitrate removal from water systems: a review," Applied Clay Science, vol. $185,2020$.

[22] B. O. Otunola and O. O. Ololade, "A review on the application of clay minerals as heavy metal adsorbents for remedia- tion purposes," Environmental Technology and Innovation, vol. 18, p. 100692, 2020.

[23] T. Zhang, W. Wang, Y. Zhao et al., "Removal of heavy metals and dyes by clay-based adsorbents: from natural clays to $1 \mathrm{D}$ and 2D nano-composites," Chemical Engineering Journal, vol. 420, 2021.

[24] A. A. Basheer, "New generation nano-adsorbents for the removal of emerging contaminants in water," Journal of Molecular Liquids, vol. 261, pp. 583-593, 2018.

[25] R. C. Lima, L. Bieseki, P. V. Melguizo, and S. B. C. Pergher, Environmentally friendly zeolites - synthesis and source materials, Springer, 2019.

[26] A. Iulianelli and E. Drioli, "Membrane engineering: latest advancements in gas separation and pre-treatment processes, petrochemical industry, and refinery, and future perspectives in emerging applications," Fuel Processing Technology, vol. 206, 2020.

[27] E. Koohsaryan, M. Anbia, and M. Maghsoodlu, "Application of zeolites as non-phosphate detergent builders: A review," Journal of Environmental Chemical Engineering, vol. 8, no. 5, p. 104287, 2020.

[28] E. Kianfar, S. Hajimirzaee, S. Mousavian, and A. S. Mehr, "Zeolite-based catalysts for methanol to gasoline process: a review," Microchemical Journal, vol. 156, p. 104822, 2020.

[29] J. M. Paris, J. G. Roessler, C. C. Ferraro, H. D. DeFord, and T. G. Townsend, "A review of waste products utilized as supplements to Portland cement in concrete," Journal of Cleaner Production, vol. 121, pp. 1-18, 2016.

[30] L. Bacakova, M. Vandrovcova, I. Kopova, and I. Jirka, "Applications of zeolites in biotechnology and medicine - a review," Biomaterials Science, vol. 6, no. 5, pp. 974-989, 2018.

[31] E. B. G. Johnson and S. E. Arshad, "Hydrothermally synthesized zeolites based on kaolinite: a review," Applied Clay Science, vol. 97-98, pp. 215-221, 2014.

[32] A. F. Masters and T. Maschmeyer, "Zeolites - From curiosity to cornerstone," Microporous and Mesoporous Materials, vol. 142, no. 2-3, pp. 423-438, 2011.

[33] M. Guisnet and J.-P. Gilson, "Introduction to zeolite science and technology," in Zeolites for Cleaner Technologies, M. Guisnet and J.-P. Gilson, Eds., vol. 3, Imperial College Press, London, 2002.

[34] Y. Li, L. Li, and J. Yu, "Applications of zeolites in sustainable chemistry," Chem, vol. 3, pp. 928-949, 2017.

[35] H. E. MgBemere, I. C. Ekpe, and G. I. Lawal, "Zeolite synthesis, characterizations, and application areas - a review," International Research Journal of Environmental Sciences, vol. 6, pp. 45-59, 2017.

[36] M. Yoldi, E. G. Fuentes-Ordoñez, S. A. Korili, and A. Gil, "Zeolite synthesis from industrial wastes," Microporous and Mesoporous Materials, vol. 287, pp. 183-191, 2019.

[37] I. Diaz and A. Mayoral, "TEM studies of zeolites and ordered mesoporous materials," Micron, vol. 42, pp. 512-527, 2011.

[38] R. Xu, W. Pang, J. Yu, Q. Huo, and J. Chen, Chemistry of Zeolites and Related Porous Materials Synthesis and Structure, John Wiley \& Sons Pte Ltd, Singapore, 2007.

[39] P. Payra and P. K. Dutta, "Zeolites: a primer," in Handbook of Zeolite Science and Technology, S. M. Auerbach, K. A. Carrado, and K. P. Dutta, Eds., Marcell Dekker, Inc., New York, 2003, Chapter 1283.

[40] J. Dong, Z. Xu, S. Yang, S. Murad, and K. R. Hinkle, "Zeolite membranes for ion separations from aqueous solutions," 
Current Opinion in Chemical Engineering, vol. 8, pp. 15-20, 2015.

[41] H. Ghobarkar, O. Schäf, and U. Guth, "Zeolites-from kitchen to space," Progress in Solid State Chemistry, vol. 27, no. 2-4, pp. 29-73, 1999.

[42] M.-C. Silaghi, C. Chizallet, and P. Raybaud, "Challenges on molecular aspects of dealumination and desilication of zeolites," Microporous and Mesoporous Materials, vol. 191, pp. 82-96, 2014.

[43] R. W. Broach, "Zeolite types and structures," in Zeolites in Industrial Separation and Catalysis, S. Kulprathipanja, Ed., WILEY-VCH, Weinheim, 2010.

[44] R. F. Lobo, "Introduction to the structural chemistry of zeolites," in Handbook of Zeolite Science and Technology, S. M. Auerbach, K. A. Carrado, and P. K. Dutta, Eds., p. 1283, Marcel Dekker, Inc., New York, 2003.

[45] C. Baerlocher, L. B. McCuster, and D. H. Olson, Atlas of Zeolite Framework Types, Elsevier, Amsterdam, 6 ed. edition, 2007.

[46] M. N. Rashed and P. N. Palanisamy, "Introductory Chapter: Adsorption and ion exchange properties of zeolites for treatment of polluted water," Zeolites and Their Applications, 2018, Chapter Chapter 1.

[47] C. Colella, "Ion exchange equilibria in zeolite minerals," Mineralium Deposita, vol. 31, pp. 554-562, 1996.

[48] R. L. Ray and R. A. Sheppard, "Occurrence of zeolites in sedimentary rocks: an overview," in Natural Zeolites: Occurrence, Properties, Applications, D. L. Bish and D. W. Ming, Eds., vol. 45, Reviews in Mineralogy and Geochemistry, New Mexico, 2001.

[49] I. Marantos, G. E. Christidis, and M. Ulmanu, Zeolite formation and deposits, Handbook of Natural Zeolites, 2012.

[50] US Geological survey, Mineral commodity summaries 2020: U.S., Geological Survey, 2020.

[51] D. M. Flanagan, Zeolites - U, S, Geological Survey Minerals Yearbook -2016, 2018.

[52] R. E. Morris, "Ionothermal synthesis of zeolites and other porous materials," in Zeolites and Catalysis, Synthesis, Reactions, and Applications, J. Cejka, A. Corma, and S. Zones, Eds., vol. 1, Wiley-VCH, Weinheim, 2010.

[53] J. Liu and J. Yu, "Toward greener and designed synthesis of zeolite materials," in Zeolites and Zeolite-Like Materials, B. F. Sels and L. F. Sels, Eds., Elsevier, Amsterdam, 2016.

[54] Y. He, S. Tang, S. Yin, and S. Li, "Research progress on green synthesis of various high-purity zeolites from natural material-kaolin," Journal of Cleaner Production, vol. 306, 2021.

[55] A. Khaleque, M. M. Alam, M. Hoque et al., "Zeolite synthesis from low-cost materials and environmental applications: a review," Environmental Advances, vol. 2, p. 100019, 2020.

[56] C. Belviso, A. Kharchenko, E. Agostinelli et al., "Red mud as aluminium source for the synthesis of magnetic zeolite," Microporous and Mesoporous Materials, vol. 270, pp. 24-29, 2018.

[57] K. Margeta, N. Zabukovec, M. Siljeg, and A. Farkas, Natural zeolites in water treatment-how effective is their use, Water Treatment, 2013, Chapter Chapter 5.

[58] S. Wang and Y. Peng, "Natural zeolites as effective adsorbents in water and wastewater treatment," Chemical Engineering Journal, vol. 156, pp. 11-24, 2010.
[59] B. de Gennaro, "Surface modification of zeolites for environmental applications," in Modified Clay and Zeolite Nanocomposite Materials, pp. 57-85, Elsevier, 2019.

[60] X. M. Lv, J. Li, H. Chen, and H. J. Tang, "Copper wastewater treatment with high concentration in a two-stage crystallization-based combined process," Environmental Technology, vol. 39, no. 18, pp. 2346-2352, 2018.

[61] M. Kadhom, N. Albayati, H. Alalwan, and M. Al-Furaiji, "Removal of dyes by agricultural waste," Sustainable Chemistry and Pharmacy, vol. 16, p. 100259, 2020.

[62] S. Morais, F. G. Costa, and M. D. L. Pereira, "Heavy metals and human health," Environmental Health-Emerging Issues and Practice, vol. 10, no. 1, pp. 227-245, 2012.

[63] K. G. Pavithra and V. Jaikumar, "Removal of colorants from wastewater: a review on sources and treatment strategies," Journal of Industrial and Engineering Chemistry, vol. 75, pp. 1-19, 2019.

[64] L. Aljerf, "High-efficiency extraction of bromocresol purple dye and heavy metals as chromium from industrial effluent by adsorption onto a modified surface of zeolite: kinetics and equilibrium study," Journal of Environmental Management, vol. 225, pp. 120-132, 2018.

[65] A. Ozkan, A. G. Sener, and H. Ucbeyiay, "Investigation of coagulation and electrokinetic behaviors of clinoptilolite suspension with multivalent cations," Separation Science and Technology, vol. 53, pp. 823-832, 2018.

[66] A. Iqbal, H. Sattar, R. Haider, and S. Munir, "Synthesis and characterization of pure phase zeolite $4 \mathrm{~A}$ from coal fly ash," Journal of Cleaner Production, vol. 219, pp. 258267, 2019.

[67] N. S. Samanta, S. Banerjee, P. Mondal, U. Bora, and M. K. Purkait, "Preparation and characterization of zeolite from waste Linz-Donawitz (LD) process slag of steel industry for removal of $\mathrm{Fe}^{3+}$ from drinking water," Advanced Powder Technology, vol. 32, pp. 3372-3387, 2021.

[68] J. Szerement, A. Szatanik-Kloc, R. Jarosz, T. Bajda, and M. Mierzwa-Hersztek, "Contemporary applications of natural and synthetic zeolites from fly ash in agriculture and environmental protection," Journal of Cleaner Production, vol. 311, 2021.

[69] M. Basiuk, R. A. Brown, D. Cartwright, R. Davison, and P. M. Wallis, "Trace organic compounds in rivers, streams, and wastewater in southeastern Alberta, Canada," Inland Waters, vol. 7, no. 3, pp. 283-296, 2017.

[70] A. M. Awad, S. M. Shaikh, R. Jalab et al., "Adsorption of organic pollutants by natural and modified clays: a comprehensive review," Separation and Purification Technology, vol. 228, 2019.

[71] M. C. Villarin and S. Merel, "Paradigm shifts and current challenges in wastewater management," Journal of Hazardous Materials, vol. 390, 2020.

[72] A. Bennett, "Legislation and market forces: regulators and wastewater reuse," Filtration \& Separation, vol. 46, pp. 1621, 2009.

[73] S. M. Dal Bosco, R. S. Jimenez, and W. A. Carvalho, "Removal of toxic metals from wastewater by Brazilian natural scolecite," Journal of Colloid and Interface Science, vol. 281, pp. 424-431, 2005.

[74] E. Alvarez-Ayuso, A. Garcia-Sanchez, and X. Querol, "Purification of metal electroplating waste waters using zeolites," Water Research, vol. 37, no. 20, pp. 4855-4862, 2003. 
[75] L. Ćurković, Š. Cerjan-Stefanović, and T. Filipan, "Metal ion exchange by natural and modified zeolites," Water Research, vol. 31, pp. 1379-1382, 1997.

[76] Z. Yuna, "Review of the natural, modified, and synthetic zeolites for heavy metals removal from wastewater," Environmental Engineering Science, vol. 33, pp. 443-454, 2016.

[77] Y. Zeng, H. Woo, G. Lee, and J. Park, “Adsorption of Cr (VI) on hexadecylpyridinium bromide (HDPB) modified natural zeolites," Microporous and Mesoporous Materials, vol. 130, pp. 83-91, 2010.

[78] C.-S. Jeon, K. Baek, J.-K. Park, Y.-K. Oh, and S.-D. Lee, "Adsorption characteristics of As (V) on iron-coated zeolite," Journal of Hazardous Materials, vol. 163, pp. 804-808, 2009.

[79] USEPA, "Batch-Type Adsorption Procedures for Estimating Soil Attenuation of Chemicals," in Agency USEP, (editor), National Technical Information Service, Ohio, 1992.

[80] E. Zanin, J. Scapinello, M. de Oliveira et al., "Adsorption of heavy metals from wastewater graphic industry using clinoptilolite zeolite as adsorbent," Process Safety and Environmental Protection, vol. 105, pp. 194-200, 2017.

[81] T. Batjargal, J.-S. Yang, D.-H. Kim, and K. Baek, "Removal characteristics of $\mathrm{Cd}(\mathrm{II}), \mathrm{Cu}(\mathrm{II}), \mathrm{Pb}(\mathrm{II})$, and $\mathrm{Zn}(\mathrm{II})$ by natural Mongolian zeolite through batch and column experiments," Separation Science and Technology, vol. 46, pp. 1313-1320, 2011.

[82] K. S. Hui, C. Y. Chao, and S. C. Kot, "Removal of mixed heavy metal ions in wastewater by zeolite $4 \mathrm{~A}$ and residual products from recycled coal fly ash," Journal of Hazardous Materials, vol. 127, no. 1-3, pp. 89-101, 2005.

[83] H. S. Ibrahim, T. S. Jamil, and E. Z. Hegazy, "Application of zeolite prepared from Egyptian kaolin for the removal of heavy metals: II. Isotherm models," Journal of Hazardous Materials, vol. 182, no. 1-3, pp. 842-847, 2010.

[84] Z. Shariatinia and A. Bagherpour, "Synthesis of zeolite NaY and its nanocomposites with chitosan as adsorbents for lead(II) removal from aqueous solution," Powder Technology, vol. 338, pp. 744-763, 2018.

[85] G. Garcia, E. Cardenas, S. Cabrera, J. Hedlund, and J. Mouzon, "Synthesis of zeolite Y from diatomite as silica source," Microporous and Mesoporous Materials, vol. 219, pp. 29-37, 2016.

[86] G. Moussavi, S. Talebi, M. Farohki, and S. R. Mojtabaee, "Removal of ammonium from water by adsorption onto synthetic zeolites $\mathrm{NaA}$ and $\mathrm{NaX}$ : a comparative parametric, kinetic, and equilibrium study," Desalination and Water Treatment, vol. 51, no. 28-30, pp. 5710-5720, 2013.

[87] H. Liu, S. Peng, L. Shu, T. Chen, T. Bao, and R. L. Frost, "Effect of $\mathrm{Fe}_{3} \mathrm{O}_{4}$ addition on removal of ammonium by zeolite NaA," Journal of Colloid and Interface Science, vol. 390, no. 1, pp. 204-210, 2013.

[88] N. Widiastuti, H. Wu, H. M. Ang, and D. Zhang, "Removal of ammonium from greywater using natural zeolite," Desalination, vol. 277, pp. 15-23, 2011.

[89] H. Fu, Y. Li, Z. Yu et al., "Ammonium removal using a calcined natural zeolite modified with sodium nitrate," Journal of Hazardous Materials, vol. 393, p. 122481, 2020.

[90] Y. Zhao, Y. Niu, X. Hu et al., "Removal of ammonium ions from aqueous solutions using zeolite synthesized from red mud," Desalination and Water Treatment, pp. 1-12, 2015.

[91] H. Lin, X. Wu, and J. Zhu, "Kinetics, equilibrium, and thermodynamics of ammonium sorption from swine manure by natural chabazite," Separation Science and Technology, vol. 51, no. 2, pp. 202-213, 2016.

[92] Y. Zhang, X. Kou, H. Lu, and X. Lv, "The feasibility of adopting zeolite in phosphorus removal from aqueous solutions," Desalination and Water Treatment, vol. 52, pp. 4298-4304, 2013.

[93] N. Hamdi and E. Srasra, "Removal of phosphate ions from aqueous solution using Tunisian clays minerals and synthetic zeolite," Journal of Environmental Sciences, vol. 24, pp. 617623, 2012.

[94] P. Roy, P. Pal, S. Sensharma, N. Das, and A. Bandyopadhyay, "Performance of zeolite powder and tubular membrane having different Si/Al ratio for removing $\mathrm{As}(\mathrm{III})$ in aqueous phase," International Journal of Applied Ceramic Technology, vol. 14, no. 3, pp. 461-473, 2017.

[95] J. Goscianska, M. Ptaszkowska-Koniarz, M. Frankowski, M. Franus, R. Panek, and W. Franus, "Removal of phosphate from water by lanthanum-modified zeolites obtained from fly ash," Journal of Colloid and Interface Science, vol. 513, pp. 7281, 2018.

[96] A. Alshameri, C. Yan, and X. Lei, "Enhancement of phosphate removal from water by $\mathrm{TiO}_{2} /$ Yemeni natural zeolite: preparation, characterization and thermodynamic," Microporous and Mesoporous Materials, vol. 196, pp. 145-157, 2014.

[97] N. Ayar, G. Keçeli, A. E. Kurtoğlu, and G. Atun, “Cationic dye adsorption onto natural and synthetic zeolites in the presence of $\mathrm{Cs}^{+}$and $\mathrm{Sr}^{2+}$ ions," Toxicological \& Environmental Chemistry, vol. 97, no. 1, pp. 11-21, 2015.

[98] S. Wang and Z. H. Zhu, "Characterisation and environmental application of an Australian natural zeolite for basic dye removal from aqueous solution," Journal of Hazardous Materials, vol. 136, no. 3, pp. 946-952, 2006.

[99] S. Oukil, F. Bali, and D. Halliche, Adsorption and Kinetic Studies of Methylene Blue on Modified HUSY Zeolite and an Amorphous Mixture of $\gamma$-Alumina and Silica, Separation Science and Technology, 2019.

[100] A. Badeenezhad, A. Azhdarpoor, S. Bahrami, and S. Yousefinejad, "Removal of methylene blue dye from aqueous solutions by natural clinoptilolite and clinoptilolite modified by iron oxide nanoparticles," Molecular Simulation, vol. 45, pp. 564-571, 2019.

[101] H. Mittal, R. Babu, A. A. Dabbawala, S. Stephen, and S. M. Alhassan, "Zeolite-Y incorporated karaya gum hydrogel composites for highly effective removal of cationic dyes," Colloids and Surfaces A: Physicochemical and Engineering Aspects, vol. 19, 2020.

[102] S. Kraljević Pavelić, V. Micek, A. Filošević et al., "Novel, oxygenated clinoptilolite material efficiently removes aluminium from aluminium chloride-intoxicated rats _in vivo_," Microporous and Mesoporous Materials, vol. 249, pp. 146-156, 2017.

[103] B. Makgabutlane, L. N. Nthunya, N. Musyoka, B. S. Dladla, E. N. Nxumalo, and S. D. Mhlanga, "Microwaveassisted synthesis of coal fly ash-based zeolites for removal of ammonium from urine," RSC Advances, vol. 10, pp. 2416-2427, 2020.

[104] A. Garg, M. Mainrai, V. K. Bulasara, and S. Barman, "Experimental investigation on adsorption of amido black 10b dye onto zeolite synthesized from fly ash," Chemical Engineering Communications, vol. 202, pp. 123-130, 2015. 
[105] S. Sivalingam and S. Sen, "Efficient removal of textile dye using nanosized fly ash derived zeolite-x: kinetics and process optimization study," Journal of the Taiwan Institute of Chemical Engineers, vol. 96, pp. 305-314, 2019.

[106] N. Jiang, R. Shang, S. G. J. Heijman, and L. C. Rietveld, "Highsilica zeolites for adsorption of organic micro-pollutants in water treatment: a review," Water Research, vol. 144, pp. 145-161, 2018.

[107] N. Jiang, R. Shang, S. G. J. Heijman, and L. C. Rietveld, "Adsorption of triclosan, trichlorophenol, and phenol by high-silica zeolites: adsorption efficiencies and mechanisms," Separation and Purification Technology, vol. 235, 2020.

[108] F. Chen, Y. Li, and A. Huang, "Hydrophilicity reversal by post-modification: hydrophobic zeolite FAU and LTA coatings on stainless-steel-net for oil/water separation," Colloids and Surfaces A: Physicochemical and Engineering Aspects, vol. 601, 2020.

[109] M. S. Hosseini Hashemi, F. Eslami, and R. Karimzadeh, "Organic contaminants removal from industrial wastewater by CTAB treated synthetic zeolite Y," Journal of Environmental Management, vol. 233, pp. 785-792, 2019.

[110] A. Kuleyin, "Removal of phenol and 4-chlorophenol by surfactant-modified natural zeolite," Journal of Hazardous Materials, vol. 144, pp. 307-315, 2007.

[111] C. B. Vidal, G. S. Raulino, A. L. Barros et al., "BTEX removal from aqueous solutions by HDTMA-modified Y zeolite," Journal of Environmental Management, vol. 112, pp. 178-185, 2012.

[112] M. Ghiaci, A. Abbaspur, R. Kia, and F. Seyedeyn-Azad, "Equilibrium isotherm studies for the sorption of benzene, toluene, and phenol onto organo-zeolites and as-synthesized MCM41," Separation and Purification Technology, vol. 40, pp. 217229, 2004.

[113] J. Wang and X. Guo, "Adsorption kinetic models: physical meanings, applications, and solving methods," Journal of Hazardous Materials, vol. 390, p. 122156, 2020.

[114] Y. Jin, Y. Wu, J. Cao, and Y. Wu, "Adsorption behavior of $\mathrm{Cr}(\mathrm{VI}), \mathrm{Ni}(\mathrm{II})$, and $\mathrm{Co}(\mathrm{II})$ onto zeolite $13 \mathrm{x}$," Desalination and Water Treatment, vol. 54, pp. 511-524, 2015.

[115] S. Bai, M. Chu, L. Zhou, Z. Chang, C. Zhang, and B. Liu, "Removal of heavy metals from aqueous solutions by Xtype zeolite prepared from combination of oil shale ash and coal fly ash," Energy Sources, Part A: Recovery, Utilization, and Environmental Effects, pp. 1-11, 2019.

[116] C. Barelocher, L. B. McCuster, and D. H. Olson, Atlas of Zeolite Framework Types, Elsevier, Amsterdam, 6 ed. edition, 2007.

[117] J. Yu, "Synthesis of zeolites," in Introduction to zeolite science and practice. Vol. 168, J. Čejka, B. Hv, A. Corma, and F. Schüth, Eds., Elsevier, 3 ed edition, 2007, Chapter 3.

[118] N. R. C. Fernandes Machado and D. M. Malachini Miotto, "Synthesis of Na-A and -X zeolites from oil shale ash," Fuel, vol. 84, pp. 2289-2294, 2005.

[119] M. A. S. D. Barros, A. S. Zola, P. A. Arroyo, E. F. SouzaAguiar, and C. R. G. Tavares, "Binary ion exchange of metal ions in Y and X zeolites," Brazilian Journal of Chemical Engineering, vol. 20, pp. 4113-4421, 2003.

[120] E. Drioli and L. Giorno, Encyclopedia of Membranes, Springer, Heidelberg, 2016.

[121] L. Ayele, J. Pérez-Pariente, Y. Chebude, and I. Díaz, "Synthesis of zeolite A from Ethiopian kaolin," Microporous and Mesoporous Materials, vol. 215, pp. 29-36, 2015.
[122] I. Garcia-Sosa and M. Solache-Rios, "Cation-exchange capacities of zeolites A, X, Y, ZSM-5, and Mexican erionite compared with the retention of cobalt and cadmium," Journal of Radioanalytical and Nuclear Chemistry, vol. 250, pp. 205206, 2001.

[123] A. S. Zola, M. A. S. D. Barros, E. F. Sousa-Aguiar, and P. A. Arroyo, "Determination of the maximum retention of cobalt by ion exchange in H-zeolites," Brazilian Journal of Chemical Engineering, vol. 29, no. 2, pp. 385-392, 2012.

[124] A. Á. B. Maia, R. N. Dias, R. S. Angélica, and R. F. Neves, "Influence of an aging step on the synthesis of zeolite $\mathrm{NaA}$ from Brazilian Amazon kaolin waste," Journal of Materials Research and Technology, vol. 8, pp. 2924-2929, 2019.

[125] P. Krongkrachang, P. Thungngern, P. Asawaworarit, N. Houngkamhang, and A. Eiad-Ua, "Synthesis of zeolite Y from kaolin via hydrothermal method," Materials Today: Proceedings, vol. 17, pp. 1431-1436, 2019.

[126] Y. Ma, C. Yan, A. Alshameri, X. Qiu, C. Zhou, and D. Li, "Synthesis and characterization of $13 \mathrm{X}$ zeolite from lowgrade natural kaolin," Advanced Powder Technology, vol. 25, no. 2, pp. 495-499, 2014.

[127] J.-Q. Wang, Y.-X. Huang, Y. Pan, and J.-X. Mi, "New hydrothermal route for the synthesis of high purity nanoparticles of zeolite Y from kaolin and quartz," Microporous and Mesoporous Materials, vol. 232, pp. 77-85, 2016.

[128] J.-Q. Wang, Y.-X. Huang, Y. Pan, and J.-X. Mi, "Hydrothermal synthesis of high purity zeolite A from natural kaolin without calcination," Microporous and Mesoporous Materials, vol. 199, pp. 50-56, 2014.

[129] L. Ayele, J. Pérez-Pariente, Y. Chebude, and I. Díaz, "Conventional versus alkali fusion synthesis of zeolite A from low grade kaolin," Applied Clay Science, vol. 132-133, pp. 485490, 2016.

[130] A. S. Kovo and S. M. Holmes, "Effect of aging on the synthesis of kaolin-based zeolite Y from Ahoko Nigeria using a novel metakaolinization technique," Journal of Dispersion Science and Technology, vol. 31, pp. 442-448, 2010.

[131] A. S. Kovo, O. Hernandez, and S. M. Holmes, "Synthesis and characterization of zeolite Y and ZSM-5 from Nigerian Ahoko kaolin using a novel, lower temperature, metakaolinization technique," Journal of Materials Chemistry, vol. 19, 2009.

[132] J.-C. Kim, M. Choi, H. J. Song et al., "Synthesis of uniformsized zeolite from windshield waste," Materials Chemistry and Physics, vol. 166, pp. 20-25, 2015.

[133] M. Tsujiguchi, T. Kobashi, M. Oki, Y. Utsumi, N. Kakimori, and A. Nakahira, "Synthesis and characterization of zeolite A from crushed particles of aluminoborosilicate glass used in LCD panels," Journal of Asian Ceramic Societies, vol. 2, pp. 27-32, 2014.

[134] P. Vinaches, J. A. B. Alves, D. M. Melo, and S. B. Pergher, "Raw powder glass as a silica source in the synthesis of colloidal MEL zeolite,” Materials Letters, vol. 178, pp. 217-220, 2016.

[135] J. A. B. L. R. Alves, E. R. S. Dantas, S. B. C. Pergher, D. D. A. Melo, and M. A. F. Melo, "Synthesis of high value-added zeolitic materials using glass powder residue as a silica source," Materials Research, vol. 17, no. 1, pp. 213-218, 2014.

[136] A. R. Majdinasab, P. K. Manna, Y. Wroczynskyj et al., "Costeffective zeolite synthesis from waste glass cullet using energy-efficient microwave radiation," Materials Chemistry and Physics, vol. 221, pp. 272-287, 2019. 
[137] J. Dufour, V. González, and A. L. Iglesia, "Synthesis of 13X zeolite from alkaline waste streams in the aluminum anodizing industry," Industrial and Engineering Chemistry Research, vol. 40, no. 4, pp. 1140-1145, 2001.

[138] E. A. Abdelrahman, "Synthesis of zeolite nanostructures from waste aluminum cans for efficient removal of malachite green dye from aqueous media," Journal of Molecular Liquids, vol. 253, pp. 72-82, 2018.

[139] N. Shigemoto, H. Hayashi, and K. Miyaura, "Selective formation of $\mathrm{Na}-\mathrm{X}$ zeolite from coal fly ash by fusion with sodium hydroxide prior to hydrothermal reaction," Journal of Materials Science, vol. 28, pp. 4781-4786, 1993.

[140] V. S. Somerset, L. F. Petrik, R. A. White, M. J. Klink, D. Key, and E. I. Iwuoha, "Alkaline hydrothermal zeolites synthesized from high $\mathrm{SiO}_{2}$ and $\mathrm{Al}_{2} \mathrm{O}_{3}$ co-disposal fly ash filtrates," Fuel, vol. 84, pp. 2324-2329, 2005.

[141] S. F. Ferrarini, A. M. Cardoso, L. Alban, and M. J. R. Pires, "Evaluation of the sustainability of integrated hydrothermal synthesis of zeolites obtained from waste," Journal of the Brazilian Chemical Society, vol. 29, pp. 1464-1479, 2018.

[142] T. Fukasawa, A. Horigome, A. D. Karisma, N. Maeda, A.N. Huang, and K. Fukui, "Utilization of incineration fly ash from biomass power plants for zeolite synthesis from coal fly ash by microwave hydrothermal treatment," Advanced Powder Technology, vol. 29, pp. 450-456, 2018.

[143] G. Itskos, A. Koutsianos, N. Koukouzas, and C. Vasilatos, "Zeolite development from fly ash and utilization in lignite mine-water treatment," International Journal of Mineral Processing, vol. 139, pp. 43-50, 2015.

[144] C. Belviso, "Ultrasonic_vs_ hydrothermal method: Different approaches to convert fly ash into zeolite. How they affect the stability of synthetic products over time?," Ultrasonics Sonochemistry, vol. 43, pp. 9-14, 2018.

[145] X. S. Zhao, Q. Q. Lu, and H. Y. Zhu, "Effects of ageing and seeding on the formation of zeolite $\mathrm{Y}$ from coal fly ash," Journal of Porous Materials, vol. 4, no. 4, pp. 245251, 1997.

[146] A. A. Ismail, R. M. Mohamed, I. A. Ibrahim, G. Kini, and B. Koopman, "Synthesis, optimization and characterization of zeolite A and its ion-exchange properties," Colloids and Surfaces A: Physicochemical and Engineering Aspects, vol. 366, pp. 80-87, 2010.

[147] J. Zhang, X. Li, J. Liu, and C. Wang, “A comparative study of MFI zeolite derived from different silica sources: synthesis, characterization and catalytic performance," Catalysts, vol. 9, 2019.

[148] W. M. Xie, F. P. Zhou, X. L. Bi et al., "Accelerated crystallization of magnetic 4A-zeolite synthesized from red mud for application in removal of mixed heavy metal ions," Journal of Hazardous Materials, vol. 358, pp. 441-449, 2018.

[149] C. Belviso, E. Agostinelli, S. Belviso et al., "Synthesis of magnetic zeolite at low temperature using a waste material mixture: fly ash and red mud," Microporous and Mesoporous Materials, vol. 202, pp. 208-216, 2015.

[150] S.-x. Bai, L.-m. Zhou, Z.-b. Chang, C. Zhang, and M. Chu, "Synthesis of Na-X zeolite from Longkou oil shale ash by alkaline fusion hydrothermal method," Carbon Resources Conversion, vol. 1, no. 3, pp. 245-250, 2018.

[151] Z. Qiang, X. Shen, M. Guo, F. Cheng, and M. Zhang, "A simple hydrothermal synthesis of zeolite $\mathrm{X}$ from bauxite tailings for highly efficient adsorbing $\mathrm{CO}_{2}$ at room temperature,"
Microporous and Mesoporous Materials, vol. 287, pp. 77-84, 2019.

[152] C. Wang, J. Zhou, Y. Wang, M. Yang, Y. Li, and C. Meng, "Synthesis of zeolite X from low-grade bauxite," Journal of Chemical Technology \& Biotechnology, vol. 88, pp. 13501357, 2013.

[153] C. Li, H. Zhong, S. Wang, J. Xue, and Z. Zhang, "A novel conversion process for waste residue: synthesis of zeolite from electrolytic manganese residue and its application to the removal of heavy metals," Colloids and Surfaces A: Physicochemical and Engineering Aspects, vol. 470, pp. 258-267, 2015.

[154] G. Yao, J. Lei, X. Zhang, Z. Sun, S. Zheng, and S. Komarneni, "Mechanism of zeolite X crystallization from diatomite," Materials Research Bulletin, vol. 107, pp. 132-138, 2018.

[155] V. Sanhueza, U. Kelm, R. Cid, and L. López-Escobar, "Synthesis of ZSM-5 from diatomite: a case of zeolite synthesis from a natural material," Journal of Chemical Technology \& Biotechnology, vol. 79, pp. 686-690, 2004.

[156] S. Mukherjee, S. Barman, and G. Halder, "Fluoride uptake by zeolite $\mathrm{NaA}$ synthesized from rice husk: isotherm, kinetics, thermodynamics, and cost estimation," Groundwater for Sustainable Development, vol. 7, pp. 39-47, 2018.

[157] Y. Wang, T. Du, Z. Qiu, Y. Song, S. Che, and X. Fang, " $\mathrm{CO}_{2}$ adsorption on polyethylenimine-modified ZSM-5 zeolite synthesized from rice husk ash," Materials Chemistry and Physics, vol. 207, pp. 105-113, 2018.

[158] Y. Wang, T. Du, X. Fang, H. Jia, Z. Qiu, and Y. Song, "Synthesis of $\mathrm{CO}_{2}$-adsorbing ZSM-5 zeolite from rice husk ash via the colloidal pretreatment method," Materials Chemistry and Physics, vol. 232, pp. 284-293, 2019.

[159] P. Xing, C. Wang, B. Ma, and Y. Chen, "Removal of Pb(II) from aqueous solution using a new zeolite-type absorbent: potassium ore leaching residue," Journal of Environmental Chemical Engineering, vol. 6, pp. 7138-7143, 2018.

[160] F.-C. Huang, Y.-L. Han, C.-K. Lee, and H.-P. Chao, "Removal of cationic and oxyanionic heavy metals from water using hexadecyltrimethylammonium-bromide-modified zeolite," Desalination and Water Treatment, vol. 57, no. 38, article 17870-9, pp. 17870-17879, 2016.

[161] C. Covarrubias, R. García, R. Arriagada, J. Yánez, and M. T. Garland, "Cr(III) exchange on zeolites obtained from kaolin and natural mordenite," Microporous and Mesoporous Materials, vol. 88, no. 1-3, pp. 220-231, 2006.

[162] S. R. Taffarel and J. Rubio, "On the removal of $\mathrm{Mn}^{2+}$ ions by adsorption onto natural and activated Chilean zeolites," Minerals Engineering, vol. 22, no. 4, p. 336, 2009.

[163] S. R. Taffarel and J. Rubio, "Removal of $\mathrm{Mn}^{2+}$ from aqueous solution by manganese oxide coated zeolite," Minerals Engineering, vol. 23, pp. 1131-1138, 2010.

[164] I. V. Joseph, L. Tosheva, and A. M. Doyle, "Simultaneous removal of $\mathrm{Cd}(\mathrm{II}), \mathrm{Co}(\mathrm{II}), \mathrm{Cu}(\mathrm{II}), \mathrm{Pb}(\mathrm{II})$, and $\mathrm{Zn}(\mathrm{II})$ ions from aqueous solutions via adsorption on FAU-type zeolites prepared from coal fly ash," Journal of Environmental Chemical Engineering, vol. 8, no. 4, p. 103895, 2020.

[165] E. R. Nightngale, "Phenomenological theory of ion solvation. Effective radii of hydrated ions," The Journals of Physical Chemistry, vol. 63, no. 9, pp. 1381-1387, 1959.

[166] Y. Marcus, "Thermodynamics of solvation of ions. Part 5.-Gibbs free energy of hydration at $298.15 \mathrm{~K}$," Journal of the Chemical Society, Faraday Transactions, vol. 87, no. 18, pp. 2995-2999, 1991. 
[167] B. Beler-Baykal and A. D. Allar, "Upgrading fertilizer production wastewater effluent quality for ammonium discharges through ion exchange with clinoptilolite," Environmental Technology, vol. 29, pp. 665-672, 2008.

[168] L. Gao, C. Zhang, Y. Sun, and C. Ma, "Effect and mechanism of modification treatment on ammonium and phosphate removal by ferric-modified zeolite," Environmental Technology, vol. 40, pp. 1959-1968, 2019.

[169] V. Hernandez-Montoya, M. A. Perez-Cruz, D. I. MendozaCastillo, M. R. Moreno-Virgen, and A. Bonilla-Petriciolet, "Competitive adsorption of dyes and heavy metals on zeolitic structures," Journal of Environmental Management, vol. 116, pp. 213-221, 2013.

[170] C. B. Vidal, A. L. Barros, C. P. Moura et al., "Adsorption of polycyclic aromatic hydrocarbons from aqueous solutions by modified periodic mesoporous organosilica," Journal of Colloid and Interface Science, vol. 357, no. 2, pp. 466-473, 2011.

[171] T. Shubair, O. Eljamal, A. Tahara, Y. Sugihara, and N. Matsunaga, "Preparation of new magnetic zeolite nanocomposites for removal of strontium from polluted waters," Journal of Molecular Liquids, vol. 288, p. 111026, 2019.

[172] D. Ma, Z. Wang, M. Guo, M. Zhang, and J. Liu, "Feasible conversion of solid waste bauxite tailings into highly crystalline 4A zeolite with valuable application," Waste Management, vol. 34, pp. 2365-2372, 2014.

[173] C. Santasnachok, W. Kurniawan, and H. Hinode, "The use of synthesized zeolites from power plant rice husk ash obtained from Thailand as adsorbent for cadmium contamination removal from zinc mining," Journal of Environmental Chemical Engineering, vol. 3, pp. 2115-2126, 2015. 